Article

\title{
Preparation of the Hybrids of Hydrotalcites and Chitosan by Urea Method and Their Antimicrobial Activities
}

\author{
Bi Foua Claude Alain Gohi ${ }^{1,2}{ }^{\circledR}$, Hong-Yan Zeng ${ }^{1, *}$, Xiao-Ju Cao ${ }^{1}$, Kai-Min Zou ${ }^{1}$, \\ Wenlin Shuai ${ }^{3}$ and Yi Diao ${ }^{2}$ \\ 1 Biotechnology Institute, College of Chemical Engineering, Xiangtan University, Xiangtan 411105, China; \\ gohibifouaca@smail.xtu.edu.cn (B.F.C.A.G.); 15773228967@163.com (X.-J.C.); \\ Kaiminzou114634987@aliyun.com (K.-M.Z.) \\ 2 School of Biological and Chemical Engineering, Panzhihua University, Panzhihua 617000, China; \\ diaoy163@163.com \\ 3 College of Chemistry and Chemical Engineering, Xinjiang University, Urumqi 830046, China; \\ swlswlsw1123456789@163.com \\ * Correspondence: hongyanzeng99@hotmail.com; Tel.: +86-731-58298175
}

Received: 30 August 2019; Accepted: 24 September 2019; Published: 28 September 2019

\begin{abstract}
Hybrid nano-supra molecular structured materials can boost the functionality of nano- or supra-molecular materials by providing increased reactivity and conductivity, or by simply improving their mechanical stability. Herein, the studies in materials science exploring hybrid systems are investigated from the perspective of two important related applications: healthcare and food safety. Interfacing phase strategy was applied, and ZnAl layered double hydroxide-chitosan hybrids, prepared by the urea method (U-LDH/CS), were successfully synthesized under the conditions of different chitosan(CS) concentrations with a $\mathrm{Zn} / \mathrm{Al}$ molar ratio of 5.0. The structure and surface properties of the U-LDH/CS hybrids were characterized by X-ray diffraction (XRD), Fourier-transform infrared spectrometer(FTIR), scanning electronmicroscopy (SEM), ultravioletvisible (UV-Vis), and zero point charge (ZPC) techniques, where the effect of CS concentration on the structure and surface properties was investigated. The use of the U-LDH/CS hybrids as antimicrobial agents against Escherichia coli, Staphylococcus aureus, and Penicillium cyclopium was investigated in order to clarify the relationship between microstructure and antimicrobial ability. The hybrid prepared in a CS concentration of $1.0 \mathrm{~g} \cdot \mathrm{L}^{-1}\left(\mathrm{U}-\mathrm{LDH} / \mathrm{CS}_{1}\right)$ exhibited the best antimicrobial activity and exhibited average inhibition zones of 24.2,30.4, and 22.3mm against Escherichia coli, Staphylococcus aureus, and Penicillium cyclopium, respectively. The results showed that the appropriate addition of CS molecules could increase antimicrobial ability against microorganisms.
\end{abstract}

Keywords: chitosan; ZnAl hydroxide; hybrid; urea method; chitosan amount; antimicrobial activity

\section{Introduction}

The use of nanostructures is known to achieve levels of functionality not possible to reach when using bulk materials [1]. It is in this context that the notion of hybrids has been introduced, which is a strategy that aims to combine different structures in order to obtain a more efficient one. An infinite number of possibilities can emerge from the combination of phases in hybrid systems [2]. Different types of hybrid materials have been studied, including organic hybrids, inorganic hybrids, and organic-inorganic hydrids. Organic hybrid systems still dominate several traditional areas of chemical science and well-known applications, such as the synthesis of pharmaceutical compounds and drugs [3]. However, the mechanical properties (resistance to temperature and environmental 
stability) of the latter limits their application fields [4]. The applications of hybrid inorganic materials range from ion exchangers, semiconductors, adsorbent, electrochemical sensor catalysts, and catalyst support $[5,6]$. The toxicity and low biocompatibility of organic-inorganic hybrids also limit their application in biomedical science and drugs production. Among the techniques used for the preparation of hybrids, mention may be made, inter alia, of: Directintercalation, in-situ polymerization, intact melt-blending, and surface-modified blending. Organic-inorganic hybrids overcome the limitations of the previous two by their non-toxicity, their biocompatibility, and the strengthening of their mechanical properties [7,8]. Bacterial pathogens are one of the primary causes of human morbidity worldwide [9]. Historically, antibiotics have been highly effective against most bacterial pathogens; however, the increasing resistance of bacteria to a broad spectrum of commonly used antibiotics has become a global health-care problem. In recent years, the use of hybrid materials with a wide range of properties and applications has increased considerably. Construction of organic-inorganic hybrid materials is a rapidly expanding field in materials chemistry for the design of advanced materials with specific structure and functionality [10]. Bio-inorganic hybrids may exhibit, not only a combination of properties from the disparate components, but also further enhanced property tunability and new synergistic properties that arise from the interactions between the biological molecules and inorganic materials [11]. Among various hybrids of inorganic and organic materials, layered double hydrotalcites (LDH) and chitosan (CS) are of particular interest due to their wide applications range. LDH and CS have received considerable attention recently due to their wide applications in a variety of areas, including chemistry, physics, materials science, and the biomedical science [12-14]. Chitosan (CS) is a naturally occurring, cationic polysaccharide composed of (1,4)-linked 2-amino-2-deoxy- $\beta$-D-glucose and 2-acetamido-2-deoxy- $\beta$-Dglucose units. Chitin is the transformed base material resulting in chitosan, which is obtained from shrimp, crab, and lower plants and animals. By changing different parameters, one can achieve the desirable targeted chitosan molecule without changing the chemical compositions [15].CS has three types of functional nucleophile groups consisting of a C-2 $\mathrm{NH}_{2}$ group, a secondary $\mathrm{C}-3 \mathrm{OH}$ group, and a C-6 primary $\mathrm{OH}$ group. $\mathrm{CS}$ is a biopolymer that presents reactive functional groups that are susceptible to chemical modification, and has been shown to be a functional polymer that can covalently graft antioxidant/antimicrobial activity onto its backbone [16].CS has shown interesting antibacterial and antifungal activities against a wide range of microorganisms when compared to other polymers and biopolymers [17].Layered double hydroxides (LDH) are composed of positively charged brucite-like layers of divalent and trivalent metal hydroxides whose excess positive charge is compensated by anions and water molecules present in the interstitial position. Among the heterostructured nanomaterials, layered nanohybrids have received intense attentions in many areas due to their unique physico-chemical and mechanical properties that cannot be obtained from other analogous nanohybrids [18]. Moreover, LDH has essential properties, such as biocompatibility, null toxicity, and allergenicity [19]. They can be represented by the general formula:

$$
\left[\mathrm{M}(\mathrm{II})_{1-x} \mathrm{M}(\mathrm{III})_{\mathrm{x}}(\mathrm{OH}) 2\right]^{\mathrm{x}+}\left[A_{x / n}^{n-} \mathrm{YH}_{2} \mathrm{O}\right]^{\mathrm{x}-},
$$

where $\mathrm{M}(\mathrm{II})=\mathrm{Mg}, \mathrm{Ni}, \mathrm{Co}, \mathrm{Cu}, \mathrm{Zn}, \mathrm{Mn} ; \mathrm{M}(\mathrm{III})=\mathrm{Al}, \mathrm{Fe}, \mathrm{Cr}, \mathrm{V} ; \mathrm{A}^{\mathrm{n}-}=\mathrm{CO}_{3}^{2-}, \mathrm{Cl}-, \mathrm{SO}_{4}^{2-}$, etc., and $\mathrm{x}=$ $0.1-0.35$.

ZnAl hydroxides are effective antimicrobial agents for bacteria such as Escherichia coli and Staphylococcusaureus due to the hydroxides $(-\mathrm{OH})$ and the nature of the metallic cations, where $\mathrm{Zn}^{2+}$ is one of the most active ones, due to its strong oligodynamic features [20]. Zinc and CS have excellent antibacterial activity [21,22]. The goal of layered double hydroxide-chitosan hybrids, prepared by the urea method (U-LDH/CS) preparation was to assess the possible antimicrobial activity of pure CS macromolecules under microbial culture medium $\mathrm{pH}$ conditions and to explore the impact of U-LDH on CS through the inorganic-organic hybrid. Since the antimicrobial properties of CS are limited to $\mathrm{pH}$ values below six [23-26], hybrid materials that have the ability to kill pathogenic bacteria and prevent bacterial colonization are desired for utilization in several application areas such as 
food-contact materials, food packaging, textiles, water purification systems, prosthetic devices, and hospital equipment surfaces. The aim here is to activate and reinforce the antimicrobial activity of pure chitosan without taking into account both the conditions of the bacterial culture medium and its molecular weight by integrating it into a hybrid structure. In this study, using interfacing phases, a surface-modified blending process that is a strategy used to obtain a set of properties in one system that are beyond the abilities of single phases [2], the $\mathrm{LDH} / \mathrm{CS}$ hybrids as antimicrobial agents were prepared in different CS concentrations by urea method, where CS was used as a soft template. In order to clarify the relationship between the microstructure and antimicrobial ability, the physico-chemical properties of the LDH/CS hybrids were characterized by XRD, FTIR, SEM, UV-Vis and $\mathrm{pH}$ of zero point charge (pHzpc) measurements. In addition, the antimicrobial activity was also evaluated.

\section{Materials and Methods}

\subsection{Experimental Materials}

Chitosan (CS, DA $\geq 91 \%$, MW 1.5.10 kD) was purchased from Sinopharm Chemical Reagent Co. Urea $\left(\mathrm{CON}_{2} \mathrm{H}_{4}\right), \mathrm{Al}\left(\mathrm{NO}_{3}\right) \cdot 9 \mathrm{H}_{2} \mathrm{O}$, and $\mathrm{Zn}\left(\mathrm{NO}_{3}\right) 2 \cdot 6 \mathrm{H}_{2} \mathrm{O}, \mathrm{KOH}$, ethanol were purchase from Heng Xing Chemical preparation Co. Ltd. (Tianjin, China). $\mathrm{NaOH}$ was purchase from Xilong Chemical Co., Ltd. (Guangdong, China) and tetracycline powder (TC) was purchased from Sigma-Aldrich (Shanghai, China).

\subsection{Preparation of $\mathrm{ZnAl} \mathrm{Hydroxide} \mathrm{and} \mathrm{CS} \mathrm{Hybrids}$}

\subsubsection{Preparation of the $\mathrm{ZnAl} \mathrm{Hydroxide} \mathrm{by} \mathrm{Urea} \mathrm{Method}$}

For the sake of comparison, $\mathrm{ZnAl}$ hydroxide $\left(\mathrm{U}-\mathrm{LDH}_{5}\right)$ with a $\mathrm{Zn} / \mathrm{Al}$ molar ratio of 5.0 was prepared using the urea method proposed by Zeng et al. (2009) [27], with slight modifications. $\mathrm{Zn}\left(\mathrm{NO}_{3}\right)_{2} \cdot 6 \mathrm{H}_{2} \mathrm{O}$ and $\mathrm{Al}\left(\mathrm{NO}_{3}\right)_{3} \cdot 9 \mathrm{H}_{2} \mathrm{O}$ (total amount of metal ions was $0.12 \mathrm{~mol}$ ) were mixed with a set up $\mathrm{Zn} / \mathrm{Al}$ molar ratio by using $600 \mathrm{~mL}$ deionized water. The mixed solution was poured into a three-necked round bottomed flask, and urea (urea/ $\mathrm{NO}_{3}{ }^{-}$molar ratio of 4: 1) was added. The reaction solution was magnetically stirred at $110^{\circ} \mathrm{C}$ for $12 \mathrm{~h}$. Then the resulting reactant was crystallized statically at $80^{\circ} \mathrm{C}$ for another $12 \mathrm{~h}$. The precipitate was centrifuged and washed thoroughly with deionized water and was subsequently dried at $80{ }^{\circ} \mathrm{C}$ overnight. The dried material was denoted as $\mathrm{LDH}$. For convenience, the resulting sample with the $\mathrm{Zn} / \mathrm{Al}$ molar ratio of 5:1 was designated as $\mathrm{U}-\mathrm{LDH}_{5}$.

\subsubsection{Preparation of the U-LDH 5 and CS Hybrids}

The hybrids (U-LDH/CS) of the LDH and chitosan (CS) were prepared under the conditions of different $\mathrm{CS}$ concentrations and a $\mathrm{Zn} / \mathrm{Al}$ molar ratio of 5.0 by the urea method. The U-LDH $\mathrm{L}_{5}$ and CS hybrids were prepared using CS molecules as a soft template. CS solutions at the CS concentrations of $0.5,1.0,1.5,2.0$, and $3.0 \mathrm{~g} \cdot \mathrm{L}^{-1}$ were separately obtained by dissolving powered CS in the solution containing $1 \%(\mathrm{w} / \mathrm{v})$ acetic acid. During the preparation of the hybrid, $400 \mathrm{~mL}$ of mixed salt solution containing $\mathrm{Zn}\left(\mathrm{NO}_{3}\right)_{2} \cdot 6 \mathrm{H}_{2} \mathrm{O}\left(0.15 \mathrm{~mol} \cdot \mathrm{L}^{-1}\right), \mathrm{Al}\left(\mathrm{NO}_{3}\right)_{3} \cdot 9 \mathrm{H}_{2} \mathrm{O}\left(0.03 \mathrm{~mol} \cdot \mathrm{L}^{-1}\right)$, and urea (urea/ $\mathrm{NO}_{3}{ }^{-}$molar ratio of 4.0) was placed into a three-necked flask. $100 \mathrm{~mL}$ of CS solution was dropped into the mixed salt solution under stirring $(300 \mathrm{rpm})$ in $\mathrm{pH} 8.5$ at room temperature. After dripping, the reaction temperature was raised to $103{ }^{\circ} \mathrm{C}$ for $12 \mathrm{~h}$ under stirring. After the reaction, it was crystallized at $80^{\circ} \mathrm{C}$ for $18 \mathrm{~h}$, filtrated, washed, and then dried at $90^{\circ} \mathrm{C}$ for $6 \mathrm{~h}$, and was denoted as U-LDH/CS. For convenience, the resulting products prepared in the CS solutions of $0.5,1.0,1.5,2.0$, and $3.0 \mathrm{~g} \cdot \mathrm{L}^{-1}$ were designated as U-LDH/CS ${ }_{0.5}, \mathrm{U}-\mathrm{LDH} / \mathrm{CS}_{1}, \mathrm{U}-\mathrm{LDH} / \mathrm{CS}_{1.5}, \mathrm{U}-\mathrm{LDH} / \mathrm{CS}_{2}$, and U-LDH/CS 3 , respectively. 


\subsection{Characterization Techniques}

It should be noted that 21 samples were analyzed and tested, including hybrid preparation methods and analytical measurements, all in triplicate.

\subsubsection{XRD Analyses}

X-ray powder diffraction (XRD) analysis was performed on a Rigaku (Tokyo, Japan) D/MAX-2500/PC with Cu Ka radiation $(\lambda=1.5405 \AA)$, with an operating voltage of $40 \mathrm{kV}$, a current of $30 \mathrm{~mA}$, a scan rate of $2^{\circ} \mathrm{min}^{-1}$, and a scanning range from 5 to $90^{\circ} 2 \theta$, in steps of $0.0334^{\circ}$ with a counting time per step of $650 \mathrm{~s}$.

\subsubsection{FTIR Analyses}

Fourier-transform infrared (FTIR) spectra of the samples were obtained with a Perkin-Elmer Spectrum One B instrument (Shanghai, China). Powder samples were molded in KBr pellets. $1 \mathrm{mg}$ of the powdered samples was carefully mixed with $250 \mathrm{mg}$ of $\mathrm{KBr}$ (infrared grade) and pelletized under a pressure of $10 \mathrm{t}$ for $1 \mathrm{~min}$. The pellets were analyzed to collect $32 \mathrm{scans}$ in the range of $4000-400 \mathrm{~cm}^{-1}$ at a resolution of $2 \mathrm{~cm}^{-1}$.

\subsubsection{SEM Analyses}

Scanning electron microscopy (SEM) was carried out using aJSM-6700F microscope (JEOL, Tokyo, Japan) operating at $15 \mathrm{keV}$. Prior to analysis, the samples were covered with gold to avoid charge effects. Samples were sputtered using ion sputtering technology at a magnification of 15,000.

\subsubsection{UV-Vis Analysis}

UV-visible (UV-Vis) spectra were recorded by spectrophotometer (Shimadzu UV-2550, Kyoto, Japan). The range of wavelengths was $200 \sim 800 \mathrm{~nm}$ using high-purity $\mathrm{BaSO}_{4}$ as a reference.

\subsubsection{Point Zero Charge Analysis}

The determination of the $\mathrm{pH}$ point of zero charge (pHzpc) of the materials was carried out using the potentiometric titration (PT) method described by Li et al. [28]. The $\mathrm{pH}$ at $\mathrm{pHzpc}$ was determined in $\mathrm{NaCl}$ solutions (inert electrolytes) with different concentrations. The experiments were carried out in a shaker at $150 \mathrm{rpm}$ and $25^{\circ} \mathrm{C}$ for $200 \mathrm{~min}$. After the experiments, the $\mathrm{pH}$ in the solution was measured while a $0.1 \mathrm{~mol} \cdot \mathrm{L}^{-1} \mathrm{NaOH}$ solution was added. The adsorption amount of $\mathrm{H}^{+}\left(\Gamma_{\mathrm{H}_{+}}\right)$and $\mathrm{OH}^{-}\left(\Gamma_{\mathrm{OH}-}\right)$ was calculated. Finally, PT curves were obtained by plotting $\left(\Gamma_{\mathrm{OH}-}-\Gamma_{\mathrm{H}_{+}}\right)$versus $\mathrm{pH}$ in $\mathrm{NaCl}$ solutions with different concentrations, and the crossover point of $\left(\Gamma_{\mathrm{OH}-}-\Gamma_{\mathrm{H}+}\right) \sim \mathrm{pHzpc}$ curves was $\mathrm{pHzpc}$, which was electrically neutral. The permanent charge density $(\sigma p)$ at pHzpc was as follows: [29].

$$
\sigma p=F\left(\Gamma_{\mathrm{OH}-}-\Gamma_{H+}\right) z p c / S_{B E T}
$$

where, $\mathrm{S}_{\mathrm{BET}}$ and $\mathrm{F}$ are the specific surface area of the samples and the Faraday constant $(96485$ $\left.\mathrm{C} \cdot \mathrm{m}^{-2}\right)$, respectively.

\subsubsection{Rheological Analysis}

Rheological compression measurements were carried out according to the norm established by $\mathrm{Yi}_{\mathrm{i}}$ et al. [30]. Circular disk-like samples with a $25 \mathrm{~mm}$ diameter and a $2 \mathrm{~mm}$ thickness were prepared on a compression mold. Rheological studies were carried out on a controlled strain rheometer, (MCR 301, Anton Paar, Austria). The dynamic (frequency sweep) tests were performed at a strain of $0.5 \%$. Storage modulus $\left(G^{\prime}\right)$ and loss modulus $\left(G^{\prime \prime}\right)$ were measured in the frequency sweep experiments performed over a frequency range of $0.1-100 \mathrm{rad} / \mathrm{s}$, with data collected at five points per decade. 


\subsubsection{Thermogravimetric Analysis}

Thermogravimetric and differential thermal gravimetric analyses (TGA-DTG) for pure U-LDH and the U-LDH composites with various CS contents was conducted on a Perkin-Elmer TGA 7-thermal analyzer (Arizona, Waltham, MA, USA) under nitrogen at a purge rate of $20 \mathrm{~mL} / \mathrm{min}$, with the scanning temperature in the range from 50 to $800{ }^{\circ} \mathrm{C}$. A platinum crucible with a heating rate of 10 and $12{ }^{\circ} \mathrm{C}$ $/ \mathrm{min}$ and a sample weight of $63.3 \mathrm{mg}$ each were used. Meanwhile, the U-LDH content in the CS composite sample was determined on the basis of the residual ash percentage and the water amount of the U-LDH/CS itself, which measured the weight loss between 200 and $400{ }^{\circ} \mathrm{C}$.

\subsection{In Vitro Antimicrobial Assay}

\subsubsection{Microorganism and Media}

The bacteria Escherichia coli (E. coli, Gram-negative bacteria, ATCC 35218), Staphylococcus aureus (S. aureus, Gram-positive bacteria, ST398) and Penicilinum cyclopium (P. cyclopium, fungi, AS 3.4513) as target organisms were from the Xiangtan University General Microbiological Culture Collection Center. The P. cyclopium strain was maintained in potato dextrose (PD) medium (Qingdao Hope Bio-Technology Co., Ltd., Qingdao, China) at $28^{\circ} \mathrm{C}$ for $72 \mathrm{~h}$. The E. coli and S. aureus strains were maintained in mineral salt (MS) media (Boyao Biotechnology Co., Ltd., Shanghai, China) in $\mathrm{pH} 7.0$ at $37^{\circ} \mathrm{C}$ for $24 \mathrm{~h}$. PD and MS are the most widely used media for growing fungi and bacteria [31,32]. All the samples were measured to obtain their $\mathrm{OD}_{600 \mathrm{~nm}}$ values for calculating the bacteriostatic concentration. The controlled test contained the nutrient medium with bacterial suspension but without antimicrobial agents.

Mineral salt (MS) agar plate medium (g. $\left.\mathrm{L}^{-1}\right)$ : (NH4) ${ }_{2} \mathrm{SO}_{4}$ 2.0, $\mathrm{NaCl}$ 5.0, $\mathrm{K}_{2} \mathrm{HPO}_{4} 1.0, \mathrm{KH}_{2} \mathrm{PO}_{4}$ 1.0, $\mathrm{MgSO}_{4}$ 0.1, $\mathrm{CaCl}_{2}$ 0.1, and agar 20 at initial $\mathrm{pH}$ 7.0. and $\mathrm{PD}$ agar plate medium $\left(\mathrm{g} \cdot \mathrm{L}^{-1}\right.$ ): potato 20.4, dextrose 20.4 , and agar 20. All media were sterilized by autoclaving at $121^{\circ} \mathrm{C}$ for $25 \mathrm{~min}$.

\subsubsection{Antimicrobial Test}

The cultures of the bacteria and fungi strains were activated twice in liquid potato dextrose and MS media, respectively, and then the culture at exponential growth phase $\left(\mathrm{OD}_{600}\right.$ around 1.2 absorbance units). All antimicrobial experiments using the three cultures were performed in $250 \mathrm{~mL}$ sterile shaking flasks (or $90 \mathrm{~mm}$ agar plates), where $100 \mathrm{~mL}$ cultures of P. cyclopium, E. coli, and S. aureus strains were transferred into the PD and MS media in sequence for the antimicrobial tests.

Antimicrobial tests were performed using an agar diffusion test method [33]. In this assay, $100 \mathrm{~mL}$ microbial suspensions were prepared, and50 $\mu \mathrm{L}$ of a bacterial suspension of E. coli, S. aureus, and $P$. cyclopium was inoculated evenly onto agar plates. The thin tableting of the sample with $1.0 \mathrm{~cm}$ diameter was placed into an agar plate with a bacterial suspension. After incubation of E. coli and S. aureus strains at $37^{\circ} \mathrm{C}$ for $24 \mathrm{~h}$ and P. cyclopium strain at $28^{\circ} \mathrm{C}$ for $72 \mathrm{~h}$, the zone of inhibition around the mesh samples was measured with digital vernier calipers in millimeters $(\mathrm{mm})$. The zone of inhibition of the samples was measured in four directions and reported as a mean value and calculated by Equation (1),

$$
\mathrm{A}=(\mathrm{D}-\mathrm{d}) / 2
$$

where $\mathrm{A}$ is the zone of inhibition, $\mathrm{D}$ is the total diameter of the thin tableting with inhibition area after incubation, and $\mathrm{d}$ is the diameter of the thin tableting of the sample before incubation. In this assay, the agar plates with different bacterial suspensions were used as reference samples. 


\section{Results and Discussion}

\subsection{Characterization of the $U-L D H / C S$ Hybrids}

\subsubsection{XRD Analyses}

The XRD pattern of pure CS molecules is showed in Figure 1a, where there is a strong reflection in the diffractogram of chitosan at $2 \theta=21.1$, corresponding to the high crystallinity of chitosan. The powder XRD patterns of the U-LDH5, U-LDH/CS ${ }_{0.5}, \mathrm{U}-\mathrm{LDH} / \mathrm{CS}_{1}, \mathrm{U}-\mathrm{LDH} / \mathrm{CS}_{1.5}, \mathrm{U}-\mathrm{LDH} / \mathrm{CS}_{2}$, and $\mathrm{U}-\mathrm{LDH} / \mathrm{CS}_{3}$ hybrids are shown in Figure $1 \mathrm{~b}$. There is a typical layered double hydroxide structure with sharp and intense (003), (006), (009), (110), and (113) reflections and broadened (015) and (018) reflections with impure phase $\mathrm{ZnO}$ in all six samples, where only the U-LDH/CS 1.5 and U-LDH/CS include impure phase $\mathrm{ZnAl}_{2} \mathrm{O}_{4}$. As seen in Table 1, the interlayer distances (d003 about $0.76 \mathrm{~nm}$ ) for the samples were typical of $\mathrm{CO}_{3}{ }^{2-}$ pillar hydroxide, indicating that CS molecules were not intercalated into the interlayer spaces between the brucite sheets. All the lattice parameters of the U-LDH/CS samples were the same as those of the $\mathrm{U}-\mathrm{LDH}_{5}$, revealing that the incorporation of CS did not change the structures of the U-LDH/CS hybrids, which still maintained the native structures. The results demonstrate that the adding of CS as a soft template is conducive to the formation of a heterojunction structure, $\mathrm{ZnO}-\mathrm{Zn}(\mathrm{OH})_{2}$, which leads to high antimicrobial activity against bacteria combined with high adhesiveness from the CS molecules.

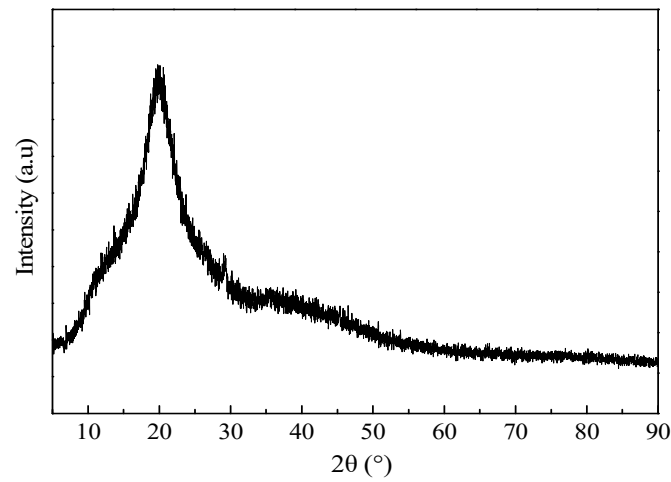

(a)

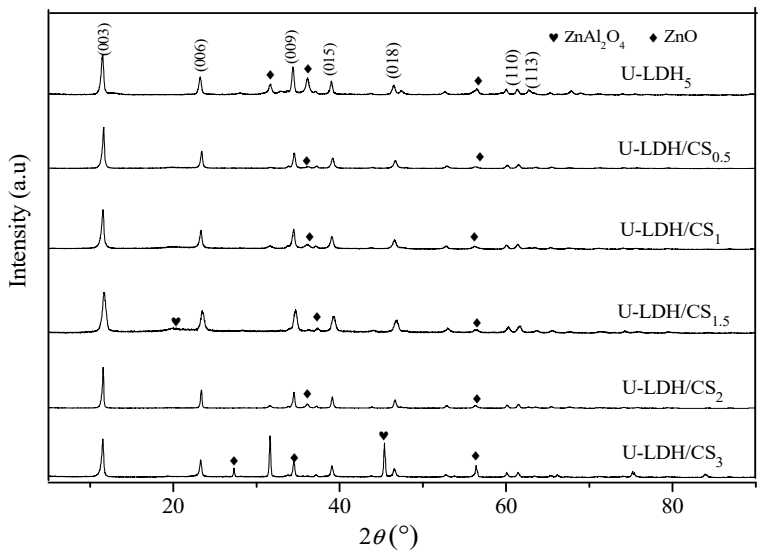

(b)

Figure 1. (a) XRD pattern of pure CS; (b) XRD patterns of the U-LDH5 and U-LDH/CS hybrids.

Table 1. Calculation of lattice parameters and basal plane for the $\mathrm{U}-\mathrm{LDH}_{5}, \mathrm{U}-\mathrm{LDH} / \mathrm{CS} \mathrm{S}_{0.5}, \mathrm{U}-\mathrm{LDH} / \mathrm{CS}_{1}$, $\mathrm{U}-\mathrm{LDH} / \mathrm{CS}_{1.5}, \mathrm{U}-\mathrm{LDH} / \mathrm{CS}_{2}, \mathrm{U}-\mathrm{LDH} / \mathrm{CS}_{3}$.

\begin{tabular}{ccccccc}
\hline Samples Reflections & U-LDH $_{\mathbf{5}}$ & U-LDH/CS $_{\mathbf{0 . 5}}$ & U-LDH/CS $_{\mathbf{1}}$ & U-LDH/CS $_{\mathbf{1 . 5}}$ & U-LDH/CS $_{\mathbf{2}}$ & U-LDH/CS $_{\mathbf{3}}$ \\
\hline$d_{003}(\mathrm{~nm})$ & 0.7691 & 0.7627 & 0.7680 & 0.7596 & 0.7659 & 0.7568 \\
$d_{006}(\mathrm{~nm})$ & 0.3828 & 0.3803 & 0.3818 & 0.3795 & 0.3813 & 0.3785 \\
$d_{009}(\mathrm{~nm})$ & 0.2487 & 0.2595 & 0.2597 & 0.2594 & 0.2598 & 0.2586 \\
$d_{110}(\mathrm{~nm})$ & 0.1631 & 0.1635 & 0.1630 & 0.1635 & 0.1636 & 0.1630 \\
$\mathrm{FW}_{003}(\mathrm{rad})$ & 0.4080 & 0.2240 & 0.2560 & 0.2990 & 0.260 & 0.5100 \\
$\mathrm{FW}_{110}(\mathrm{rad})$ & 0.7770 & 0.4760 & 0.1810 & 0.6500 & 0.79 & 0.6700 \\
$a(\mathrm{~nm})$ & 0.3262 & 0.3204 & 0.3895 & 0.2493 & 0.1640 & 0.9613 \\
$c(\mathrm{~nm})$ & 2.3073 & 2.2471 & 2.2743 & 2.2802 & 2.2097 & 2.2174 \\
\hline
\end{tabular}

\subsubsection{FTIR Analyses}

The FTIR spectra of the pure CS, U-LDH ${ }_{5}$, and U-LDH/CS samples in the range of $4000-400 \mathrm{~cm}^{-1}$ are displayed in Figure 2. As can be seen from Figure 2, all samples show significant absorption peaks 
at about 3460, 1650, and $1366 \mathrm{~cm}^{-1}$ [34,35]. For the pure CS, these three peaks belong to the stretching vibration of $-\mathrm{C}-\mathrm{OH}$ or the stretching vibration absorption peak of $-\mathrm{N}-\mathrm{H}$, the absorption peaks of amide I and amide II [36], and carboxylic acid $(-\mathrm{C}=\mathrm{O})$ or $\mathrm{C}-\mathrm{OH}$ [37], respectively. Concerning U- $\mathrm{LDH}_{5}$, the peeks are attributed to $-\mathrm{OH}$ stretching vibration and interlayer $\mathrm{H}_{2} \mathrm{O}$ absorption for $3460 \mathrm{~cm}^{-1}$, bending vibration of adsorbed water and inter-laminar structure water for $1650 \mathrm{~cm}^{-1}$, and $v 3$ stretching vibration characteristic of $\mathrm{CO}_{3}{ }^{2-}$ at $1366 \mathrm{~cm}^{-1}$. In addition to those three common peaks, pure CS at $2921 \mathrm{~cm}^{-1}$ has a stretching vibration peak of symmetrical or asymmetric $-\mathrm{CH}_{2}$ [38] on a pyranose ring of the chitosan molecule and an oscillation absorption peak of $-\mathrm{OH}$ and $-\mathrm{CH}$ on the pyranose ring at 1435 $\mathrm{cm}^{-1}$ [39], and an absorption peak of -COC- on the glycosidic bond at $1082 \mathrm{~cm}^{-1}$. Regarding U-LDH ${ }_{5}$, its FTIR presented a vibrational absorption peak of the lattice layer $\mathrm{M}-\mathrm{O}(\mathrm{Zn}-\mathrm{O}, \mathrm{Al}-\mathrm{O})$ of the main body of the hydrotalcite in the range of $1000-400 \mathrm{~cm}^{-1}$. The characteristic absorption peaks of chitosan molecules appear at about 2921, 1435, and $1082 \mathrm{~cm}^{-1}$ in U-LDH/CS $0.5, \mathrm{U}-\mathrm{LDH} / \mathrm{CS}_{1}, \mathrm{U}-\mathrm{LDH} / \mathrm{CS}_{1.5}$, $\mathrm{U}-\mathrm{LDH} / \mathrm{CS}_{2}$, and U-LDH/CS 3 compared to U-LDH ${ }_{5}$, indicating that chitosan and ZnAl-LDH are organically bound to CS and form hydrotalcite-chitosan composite material.

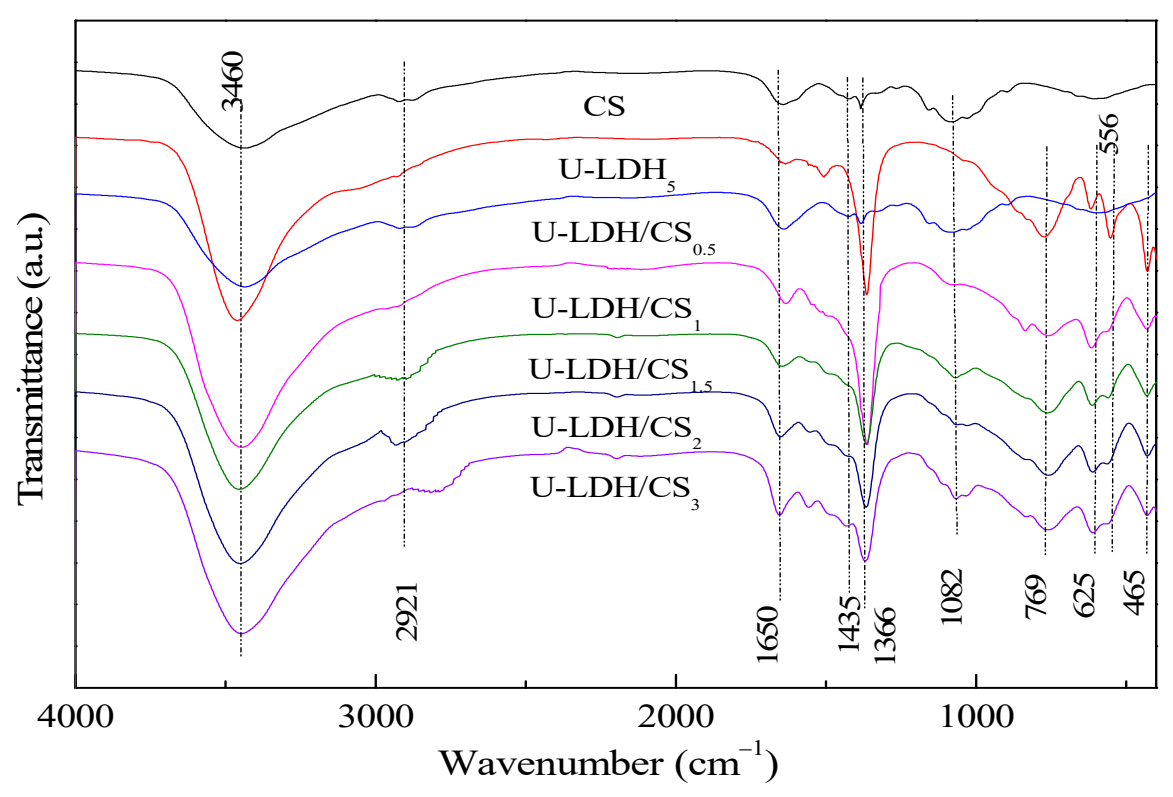

Figure 2. FTIR spectra of pure CS, U-LDH ${ }_{5}$, and U-LDH/CS hybrids.

\subsubsection{SEM Analysis}

In order to investigate the morphology of the hybrids, the U-LDH $\mathrm{LD}_{5}$ and U-LDH/CS hybrids were observed by SEM, and the results are shown in Figure 3. As shown in Figure 3, all samples (U-LDH and U-LDH/CS) exhibit a typical hydrotalcite laminate structure, which is typical of LDH. There is a certain degree of aggregation, which is due to the addition of CS leading to the U-LDH 5 bonding accumulation. Obviously, CS has an effect on the microstructure of the U-LDH/CS hybrids. 

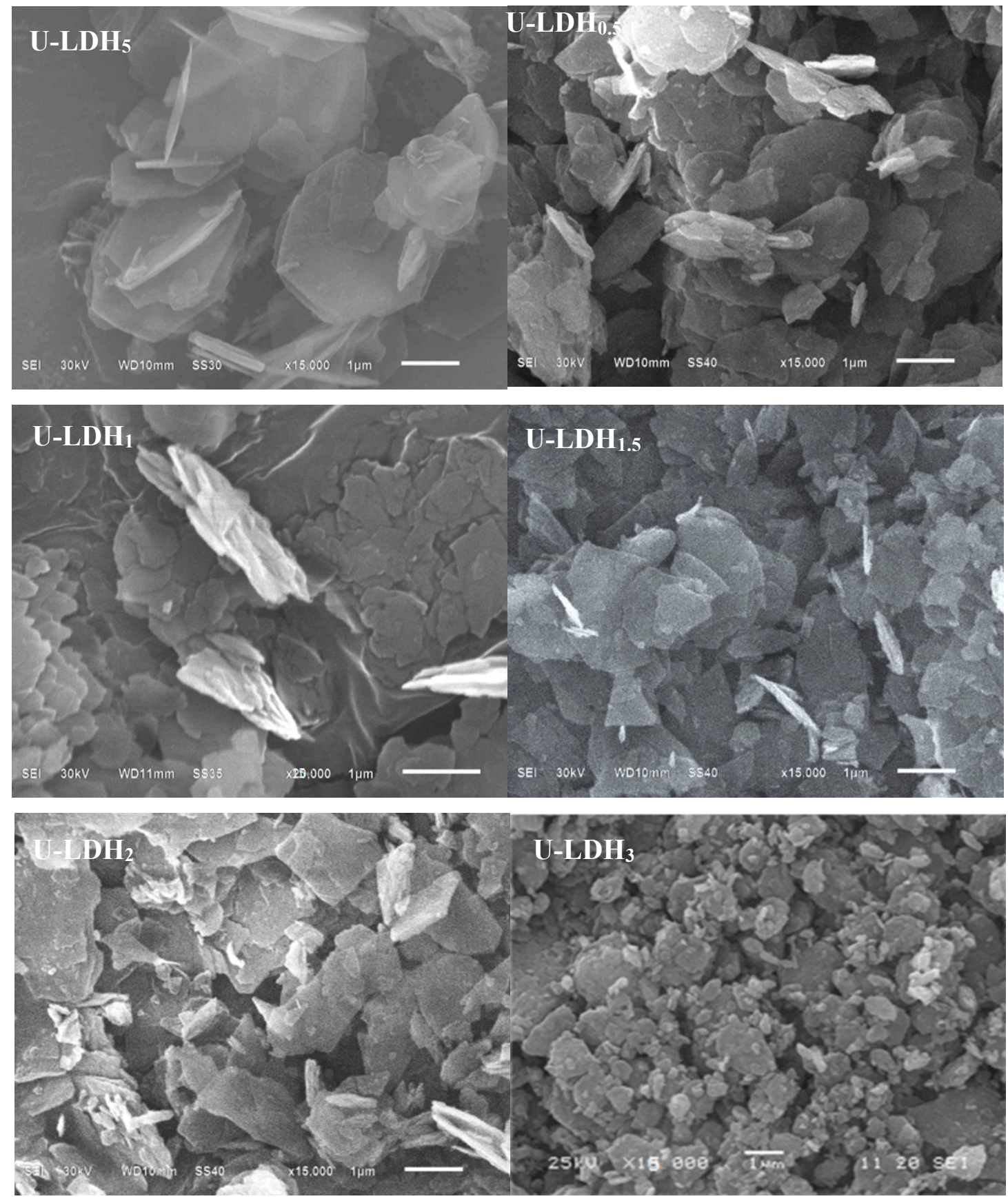

Figure 3. SEM images of the U-LDH ${ }_{5}$ and U-LDH/CS samples, $\times 15,000$.

\subsubsection{UV-Vis Analyses}

UV-Vis measurement is a very simple method that is used to probe the possible changes in the molecule structure of materials. As can be seen from Figure 4, CS exhibits a strong absorption band in a wide range from 230 to $500 \mathrm{~nm}$, with the electronic transition of $n \rightarrow \sigma^{*}$ and $n \rightarrow \pi^{*}$ belonging to $-\mathrm{NH}_{2}$ at $\sim 230 \mathrm{~nm}$ and $-\mathrm{C}=\mathrm{O}$ or $-\mathrm{COOH}$ between 220 to $500 \mathrm{~nm}$. U-LDH/CS samples show a weaker absorption band at 250-400 nm, which is due to the complexation of CS with U-LDH, which makes U-LDH/CS exhibit the absorption characteristic of chitosan UV-Vis. On the other hand, with the increase of the amount of chitosan, the absorption intensity of U-LDH/CS in this range also increases. At the same time, the intensity in the absorption band increases, with CS concentration arriving at the highest for U-LDH/CS 1.5 . With a further increase of the CS concentration, the intensity gradually decreases. This suggests that CS has been incorporated into the U-LDH/CS hybrids and impacts the 
structure of the U-LDH/CS hybrids. This further confirms that CS and ZnAl-LDH have been combined to form the U-LDH/CS complex.

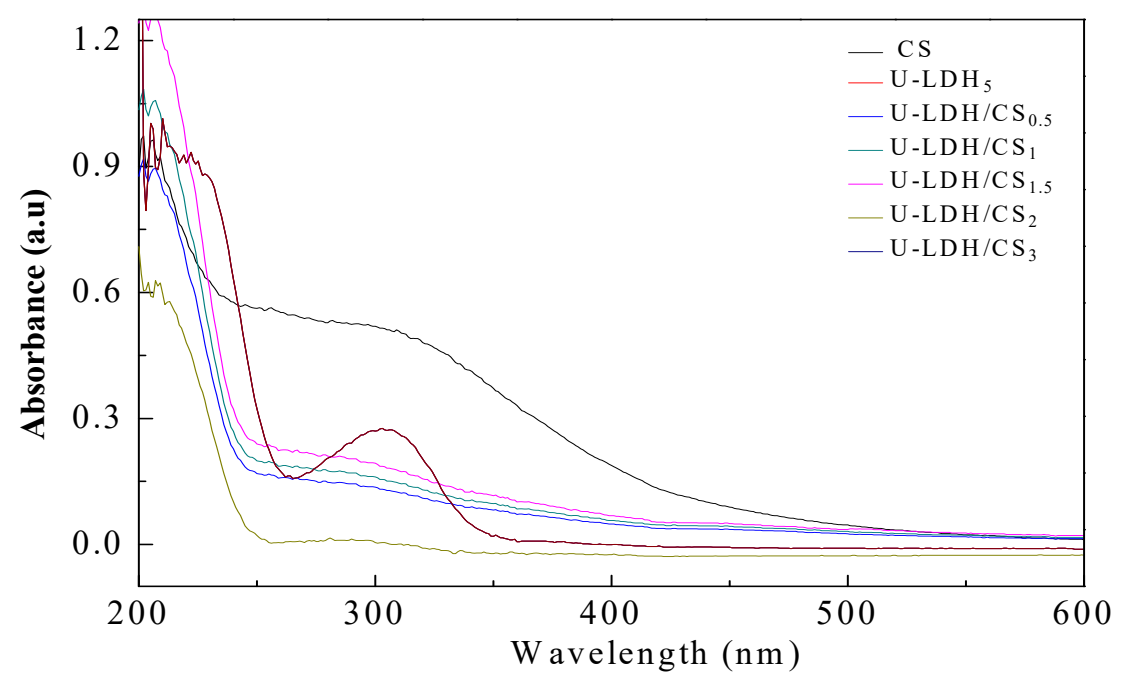

Figure 4. UV-Vis DRS spectra of the pure CS, U-LDH ${ }_{5}$, and U-LDH/CS samples.

Based on the XRD, FTIR, and UV-Vis characterization analyzes, supported by studies on "Antimicrobial Chitosan and Chitosan Derivatives" by Sahariah and Masson [23] and "Polymer-inorganic supramolecular nanohybrids for red, white, green, and blue applications" by Park et al. [40], the probable structure of the hybrid could be presented as the scheme in Figure 5.

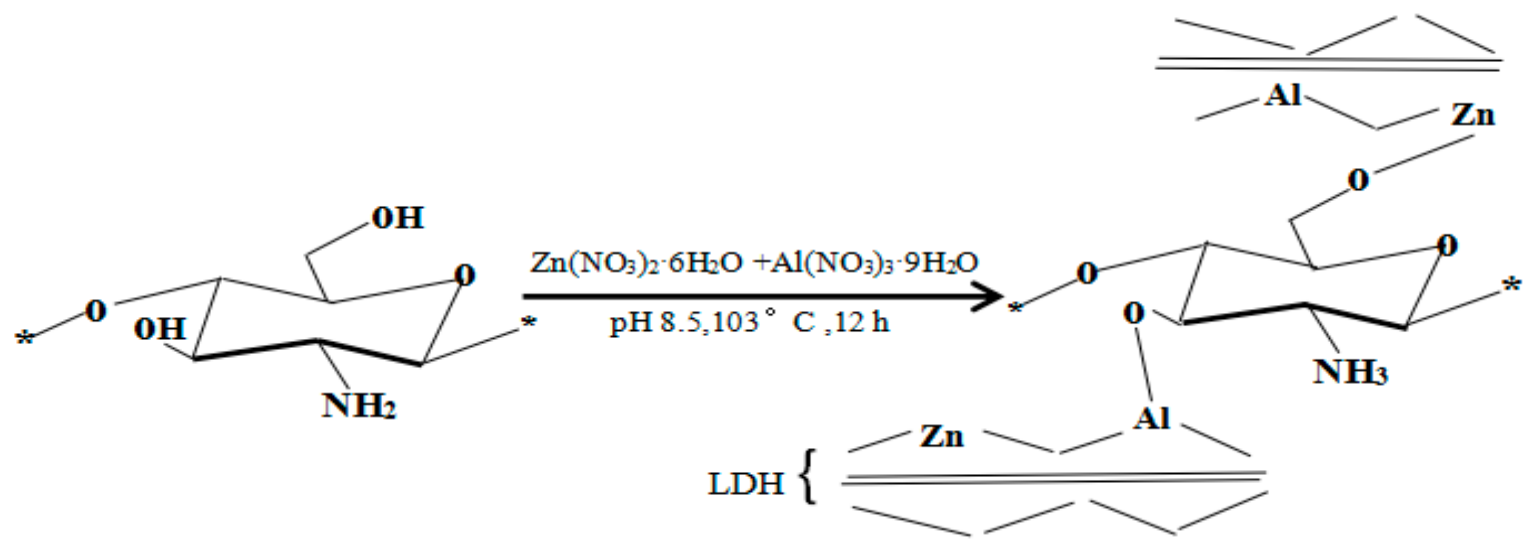

Figure 5. Synthetic scheme of U-LDH/CS hybrids.

\subsubsection{Point Zero Charge Analysis}

Figure 6 shows the relationship between $\left(\Gamma_{\mathrm{OH}^{-}}-\Gamma_{\mathrm{H}}\right)$ and the $\mathrm{pH}$ of U-LDH/CS. The difference between the adsorbed amount of $\mathrm{OH}^{-}$and $\mathrm{H}^{+}$on the surface of solid particles $\left(\Gamma_{\mathrm{OH}^{-}} \Gamma_{\mathrm{H}}\right)$ is positive, indicating that the sample surface is alkaline with a permanent positive charge. The point zero-charge-pHpzcs of U-LDH/CS $0.5, \mathrm{U}-\mathrm{LDH} / \mathrm{CS}_{1}, \mathrm{U}-\mathrm{LDH} / \mathrm{CS}_{1.5}, \mathrm{U}-\mathrm{LDH} / \mathrm{CS}_{2}$, and U-LDH/CS 3 were $11.38,11.31,11.39,11.30$, and 11.00, respectively. Among them, pHpzcs of U-LDH/CS 1.5 was the highest. According to Equation (2), the surface permanent positive charge density ( $\sigma \mathrm{p}$ ) of U-LDH/CS 0.5 , $\mathrm{U}-\mathrm{LDH} / \mathrm{CS}_{1}, \mathrm{U}-\mathrm{LDH} / \mathrm{CS}_{1.5}, \mathrm{U}-\mathrm{LDH} / \mathrm{CS}_{2}$, and U-LDH/CS 3 were $3.59,3.47,3.55,3.71$, and $3.55 \mathrm{C} / \mathrm{m}^{-2}$, respectively. The shifts in $\mathrm{pH} \mathrm{Hzc}$ and $\sigma p$ of the U-LDH/CS hybrids to higher values were believed to be linked with the incorporation of CS molecules. 

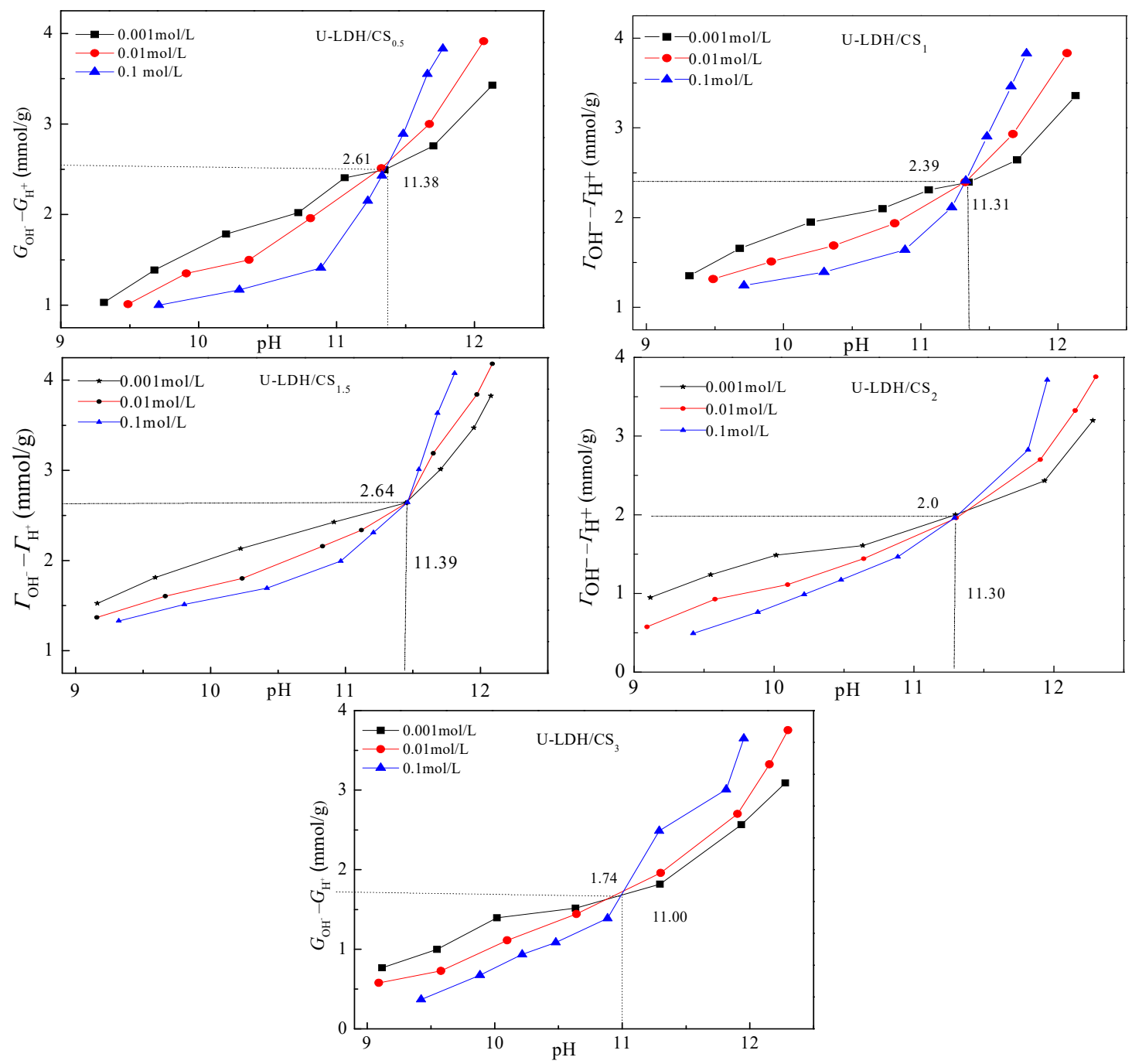

Figure 6. Potentiometric titration curves of the U-LDH/CS samples.

\subsubsection{Rheological Analysis}

Rheological properties are indicative of melt-processing behavior in unit operations such as injection molding. The linear viscoelastic responses of pure CS and the U-LDH hybrid in melt state were studied with the help of dynamic oscillatory shear measurements, and were reported in terms of storage modulus $\left(\mathrm{G}^{\prime}\right)$ (Figure $7 \mathrm{a}$ ) and complex viscosity $\left(\mathrm{n}^{*}\right)$ (Figure $7 \mathrm{~b}$ ). At a fixed frequency, the $\left(G^{\prime}\right)$ values of the hybrids are higher than those of pure CS, however, the $\left(\eta^{*}\right)$ values of hybrid are lower than those of pure CS. Consequently, the decrease of the viscosity $\left(\mathrm{n}^{*}\right)$ has gone up with the increase of U-LDH content. The viscous response of the material is stronger than the elastic response. These results demonstrate that the incorporation of U-LDH could reduce the viscosity properties of the CS matrix. The viscoelastic response in the low and medium frequencies region indicate that the hybrids have an obvious difference in their behavior from that of pure CS. One behavioral difference is that with the increase of CS content, the dependence of $\left(\mathrm{n}^{*}\right)$ on frequency becomes weaker, while the dependence of $\left(G^{\prime}\right)$ on frequency becomes stronger in the low frequency region. This non-terminal behavior may be attributed to the fact that the intercalated U-LDH layers weaken the mobility of the CS chains and then restrict the long-range relaxation of them [41,42]. U-LDH/CS 3 shows a fragility to remain compact. 


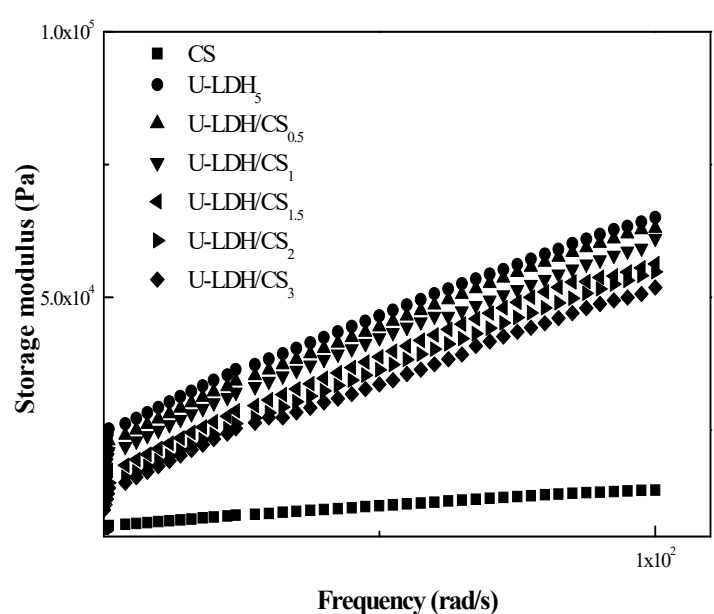

(a)

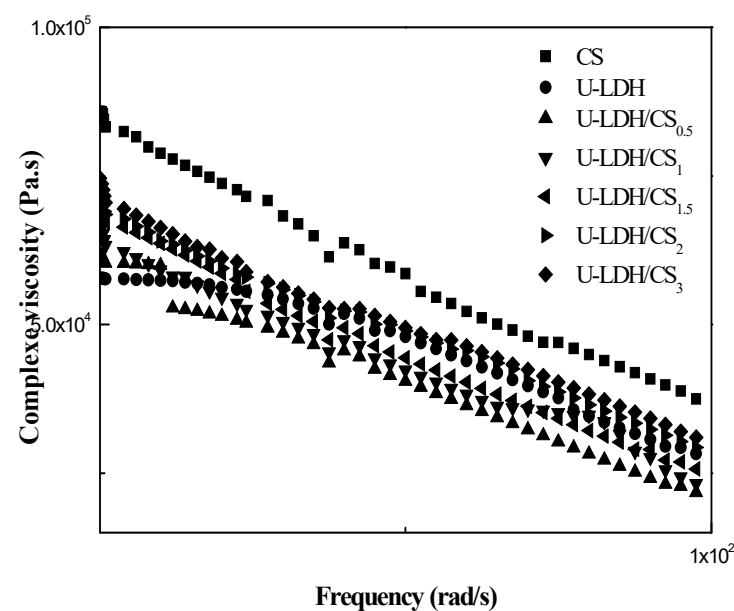

(b)

Figure 7. Storage modulus $\mathrm{G}^{\prime}$ (a) andloss modulus $\mathrm{G}^{\prime \prime}(\mathbf{b})$ of the pure CS, U- $\mathrm{LDH}_{5}$, and U-LDH/CS samples.

\subsubsection{Thermogravimetric Analysis}

Thermogravimetric Analysis (TG/DTG) is a thermal analysis technique that analyzes the composition and structure of materials and their thermal stability by measuring the relationship between mass loss and temperature during temperature control. To understand the thermal stability of CS, U-LDH ${ }_{5}$, and U-LDH/CS with different CS concentrations, we performed TG/DTG analysis of each sample. Figure $8 \mathrm{a}-\mathrm{g}$ shows the TG/DTG curves of the CS, U-LDH ${ }_{5}$, and U-LDH/CS samples. The hydration properties of CS polysacharides depend on primary and supra macromolecular structure [43]. The decomposition of chitosan is presented in two stages, the first one, which occurred at $50{ }^{\circ} \mathrm{C}$ and extended to about $75^{\circ} \mathrm{C}$, was due to loss of water molecules, with a weight loss of about $9.3 \%$ [44], followed by stability from $75^{\circ} \mathrm{C}$ to about $250^{\circ} \mathrm{C}$. Then a second stage, corresponding to the primary degradation of the pure CS, happened at $250{ }^{\circ} \mathrm{C}$, with a percentage weight loss of about $49.3 \%$ from 250 to $550^{\circ} \mathrm{C}$, which was similar to the literature [43]. A slow degradation trend occurred after $550{ }^{\circ} \mathrm{C}$ that stabilized as it approaches $800^{\circ} \mathrm{C}$. Generally, in CS, the decomposition process of the $\mathrm{N}$-acetylated compound is overlapped by the $\mathrm{N}$-deacetylated unit, thereby increasing the widening process seen at temperatures up to $400^{\circ} \mathrm{C}$ [45], CS had a total mass loss of approximately $65.6 \%$.

As can be seen from Figure $8 \mathrm{~b}$, the U-LDH 5 thermal decomposition process is divided into three stages [46,47], between $247 \sim 300{ }^{\circ} \mathrm{C}$ for the first phase of weight loss, which is due to the removal of water from the interlayer and the physical adsorption surface [48]. At this step, $\mathrm{U}_{-} \mathrm{LDH}_{5}$ remained a layered structure. The second stage of weight loss, between 300 and $450{ }^{\circ} \mathrm{C}$, was due to the decomposition of the interlayer $\mathrm{CO}_{3}^{2-}$ and the removal of the hydrotalcite-plate-OH, marking the delamination of the layered structure [49]. The last weight lost, that can be attributed to the decomposition of carbonate ions in the interlayer, started after $700{ }^{\circ} \mathrm{C}$ [50]. From Figure $8 \mathrm{~b}$, the mass loss of U-LDH $\mathrm{L}_{5}$ was $6 \%$ in the first stage, corresponding to a maximum endothermic peak of $300^{\circ} \mathrm{C}$ for DTG. The mass loss of the second phase of $1.5 \%$ corresponded to an observed edge of DTG at $448^{\circ} \mathrm{C}$. The last stage of U-LDH weight loss presented an edge at $570{ }^{\circ} \mathrm{C}$, corresponding to a $8.2 \%$ weight loss with a total weight loss ofU-LDH 5 of about $16.5 \%$. The TGA-DTA curves of U-LDH/CS at different CS concentration, shown in Figure $8 \mathrm{c}-$ ghave a quite similar trend with a difference in weight loss and endothermic peaks range. $\mathrm{U}-\mathrm{LDH} / \mathrm{CS}_{0.5}$ showed a first mass loss of $2 \%$ at $75^{\circ} \mathrm{C}$ between 50 and $102{ }^{\circ} \mathrm{C}$, which can be accredited to the loss of adsorbed water, followed by a second stage of weight loss of U-LDH/CS 0.5 from $150^{\circ} \mathrm{C}$ to $450{ }^{\circ} \mathrm{C}$ of $30 \%$, with the maximum endothermic peak at $180.6^{\circ} \mathrm{C}$. U-LDH/CS ${ }_{0.5}$ weight loss of the third stage was $4.07 \%$, with the maximum endothermic peak at $650.1{ }^{\circ} \mathrm{C}$, and the total weight loss was $36.7 \%$. $\mathrm{U}-\mathrm{LDH} / \mathrm{CS}_{0.5} \mathrm{TGA}$ showed a gradual stabilization after $700^{\circ} \mathrm{C}$, which proceeded a new slight weight 
loss of mass then a definitive stabilization up to $800^{\circ} \mathrm{C}$. The first and second phases of U-LDH/CS 1 mass loss were $8.36 \%\left(40-190{ }^{\circ} \mathrm{C}\right)$ and $26.72 \%\left(200-450^{\circ} \mathrm{C}\right)$, respectively, corresponding to the maximum endothermic peak at 163.4 and $275.9^{\circ} \mathrm{C}$. The third and last phase was $5.01 \%$ at $750{ }^{\circ} \mathrm{C}$, corresponding to an extension of the primary degradation of the pure CS associated with decomposition of the hydrotalcite interlayer. The total weight loss of U-LDH/CS 1 was $40.09 \%$. It was also noted that the total mass losses of U-LDH/CS 1.5 , U-LDH/CS 2 , and U-LDH/CS 3 were $46.3 \%, 51.3 \%$, and $68.4 \%$, respectively, distributed over two phases. These phases corresponded to a loss of water molecules, similar to the first phase of degradation of chitosan for the first stage, and the second stage was due to the primary degradation of the pure CS associated with decomposition of the interlayer and carbonate ions of hydrotalcite. The DTG curve of U-LDH/CS 1.5 had two maximum endothermics peaks at $75{ }^{\circ} \mathrm{C}$ over the range $50-150^{\circ} \mathrm{C}$ and the second at $220^{\circ} \mathrm{C}$ between 150 and $250{ }^{\circ} \mathrm{C}$ in addition to two edges at 260 and $460^{\circ} \mathrm{C}$. The DTG curves of U-LDH/CS 2 and U-LDH/CS 3 exhibited three maximum endothermic peaks in the same temperature ranges and one edge each. Their maximum endothermic peaks were at the same locations at $75^{\circ} \mathrm{C}, 180^{\circ} \mathrm{C}$, and $280^{\circ} \mathrm{C}$ in the interval ranges of 50 to $100{ }^{\circ} \mathrm{C}, 100$ to $200{ }^{\circ} \mathrm{C}$, and 200 to $300{ }^{\circ} \mathrm{C}$, respectively. It was only the edges whose positions were different; one at $550{ }^{\circ} \mathrm{C}$ for U-LDH/CS 2 and the other at $530^{\circ} \mathrm{C}$ for U-LDH/CS 3 . TG/DTG curves showed that CS molar ratio changes had a strong effect on the thermal stability of the hybrid, indicating that even though the CS molar ratio increased, the charge density of the laminate decreased, but the hydrogen bonding between the interlayer $\mathrm{H}_{2} \mathrm{O}$ and the interlayer $\mathrm{CO}_{3}^{2-}, \mathrm{OH}$ - anion, the interlayer $-\mathrm{OH}$, and the interlayer anion interactions were not affected much. It is worth mentioning that U-LDH/CS ${ }_{2}$ and U-LDH/CS 3 showed a strong phase of weight loss at $200-550{ }^{\circ} \mathrm{C}$, with a mass loss of $48.6 \%$ and $51.3 \%$, respectively. These losses may be due to the hybrid U-LDH/CS arrangement during the formation of spinel transformation given the high concentration of CS. Obviously, increasing the concentration of CS for the preparation of U-LDH/CS induced the decrease of the thermal resistance of the U-LDH/CS hybrid.

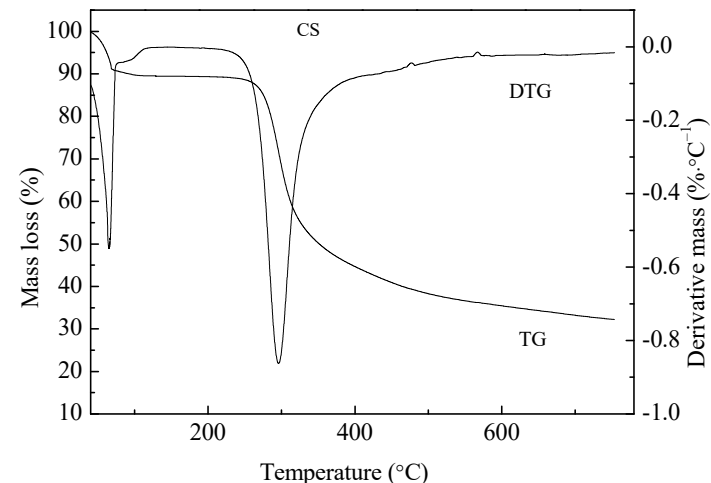

(a)

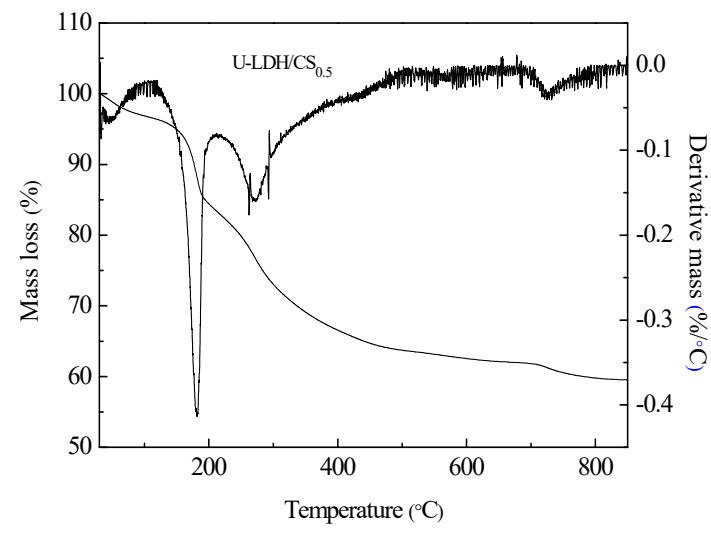

(c)

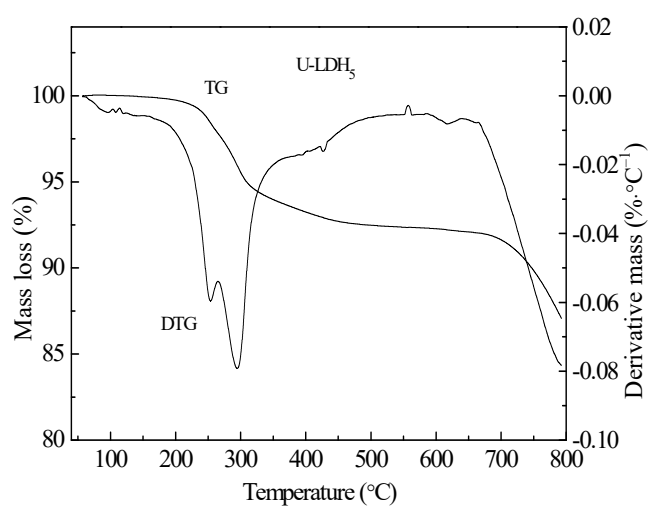

(b)

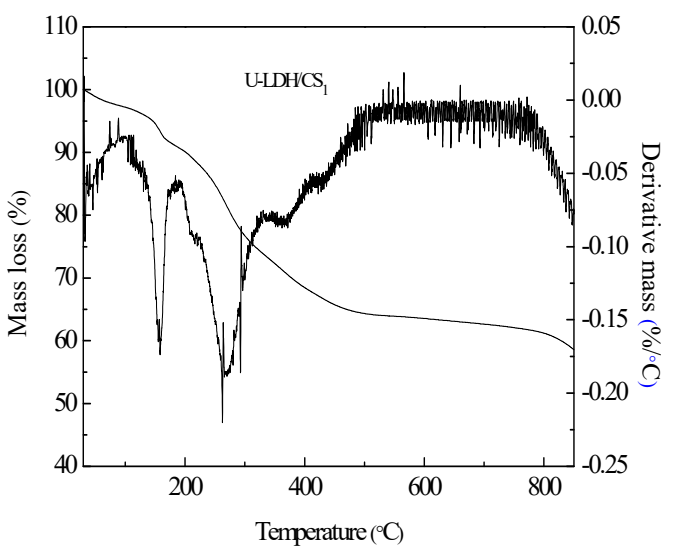

(d)

Figure 8. Cont. 


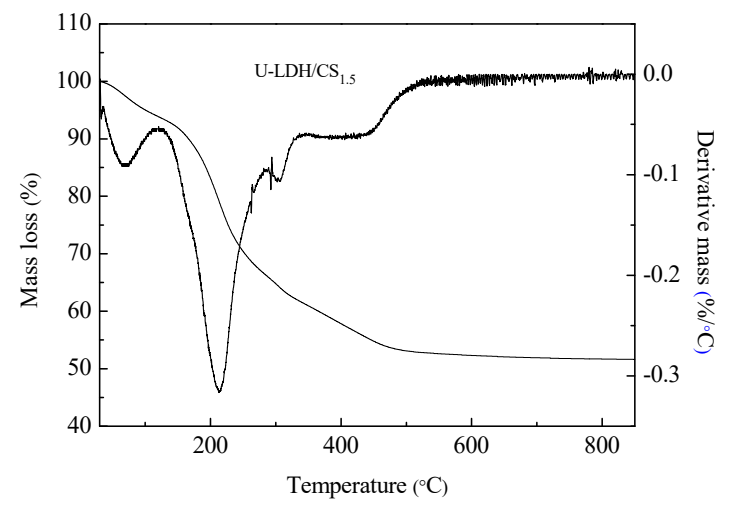

(e)

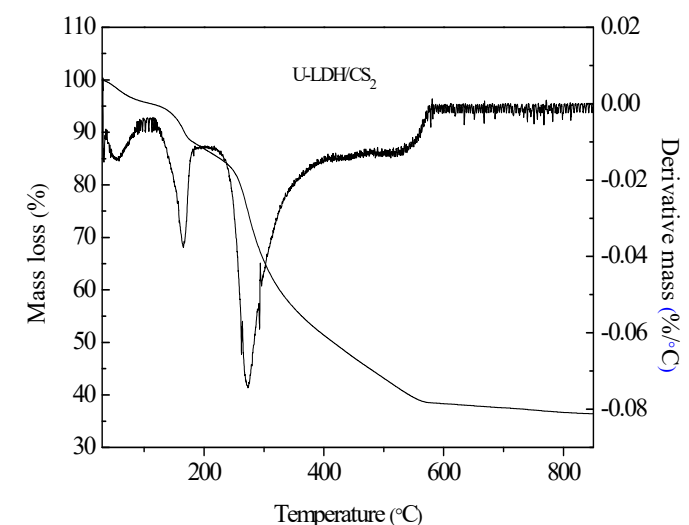

(f)

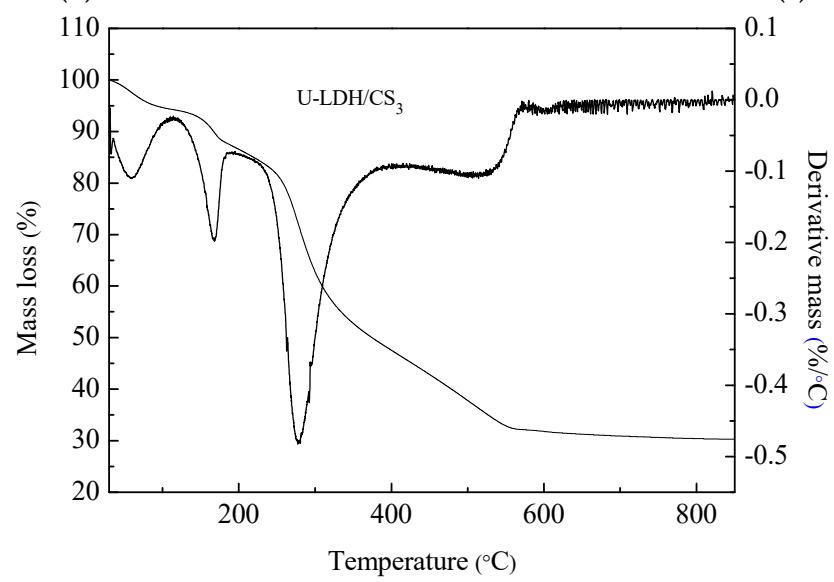

(g)

Figure 8. Thermal gravimetric and differential thermal gravimetric TGA-DTG curves of (a) pure CS; (b) $\mathrm{U}-\mathrm{LDH}_{5} ;$ (c) U-LDH/CS $0.5 ;$ (d) U-LDH/CS 1 ; (e) U-LDH/CS $1.5 ;$ (f) U-LDH/CS ${ }_{2}$; (g) U-LDH/CS 3 .

\subsection{Antimicrobial Activity}

The antimicrobial activities of the pure CS and U-LDH/CS hybrids prepared in different CS concentration were measured according to the inhibition zone diameter method, and the results are shown in Figure 9a-c. All samples were tested against E. coli, S. aureus, and P. cyclopium. As seen in Figure $9 \mathrm{a}-\mathrm{c}$ and Table 2, the control, pure CS (Figure S1), and U-LDH/CS 3 meshes did not display antimicrobial activity, while the U-LDH/CS 0.5 and U-LDH/CS 1 meshes exhibited strong antimicrobial activity against the three microorganisms. In particular, $\mathrm{U}-\mathrm{LDH} / \mathrm{CS}_{1}$ showed the highest antimicrobial ability and produced average inhibition zones of $24.2,30.4$, and $22.3 \mathrm{~mm}$ against E. coli, S. aureus, and P. cyclopium, respectively. The antimicrobial activity of U-LDH/CS 1 was much larger than that of $\mathrm{U}_{-} \mathrm{LDH}_{5}$ due to the incorporation of CS molecules. The results suggest that the hybrids of chitosan and ZnAl-LDH made for the improvement of antimicrobial ability. 

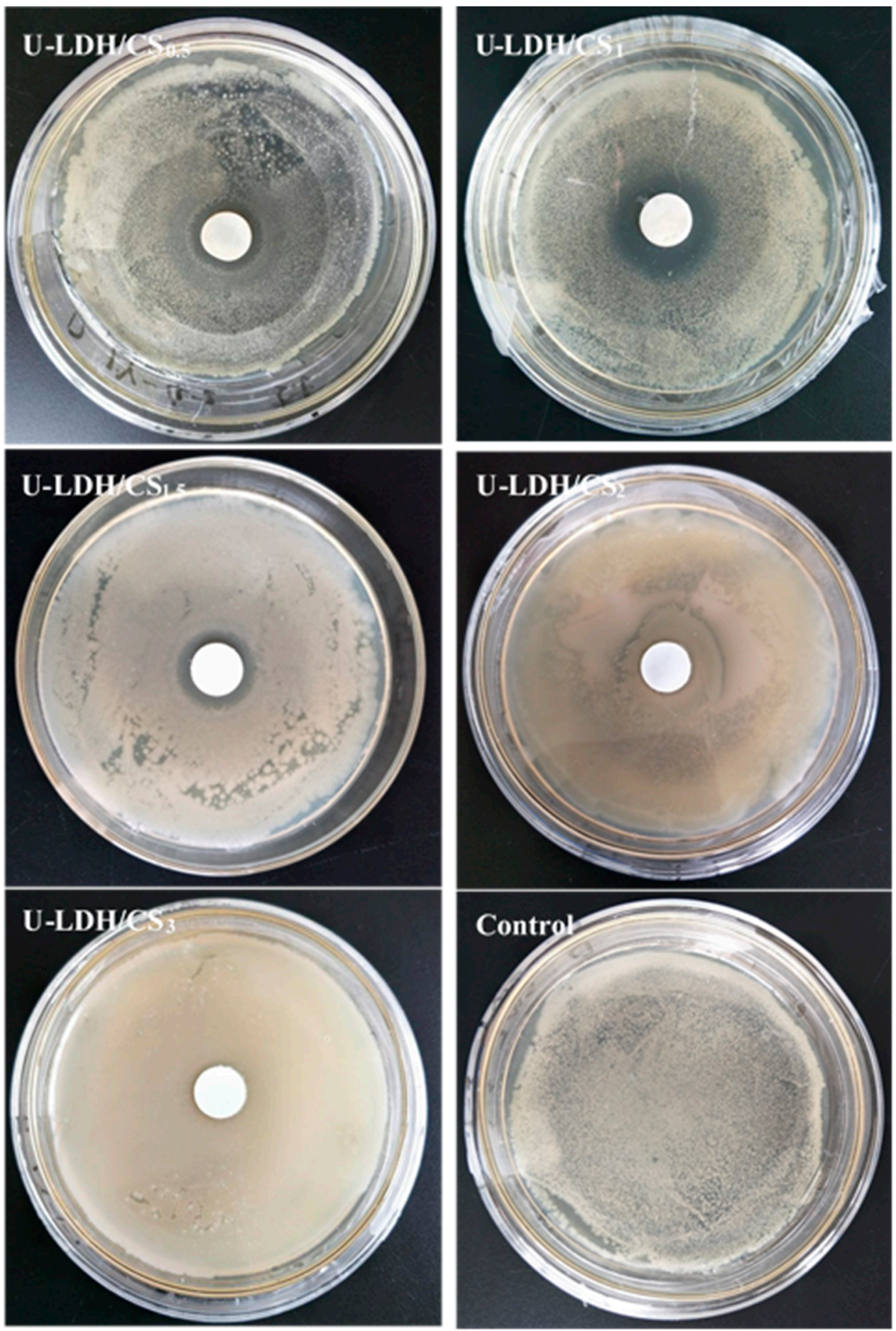

(a)

Figure 9. Cont. 

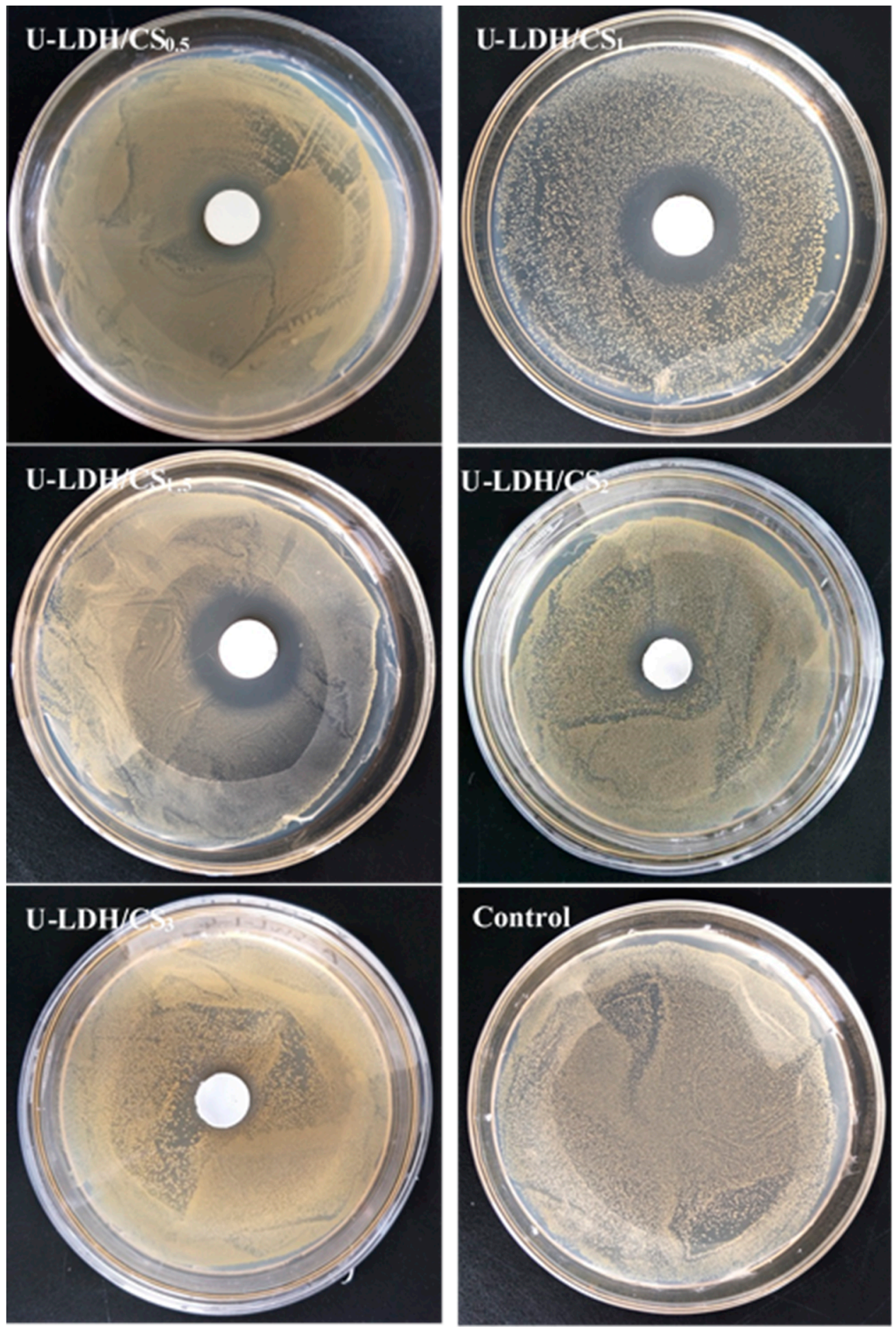

(b)

Figure 9. Cont. 

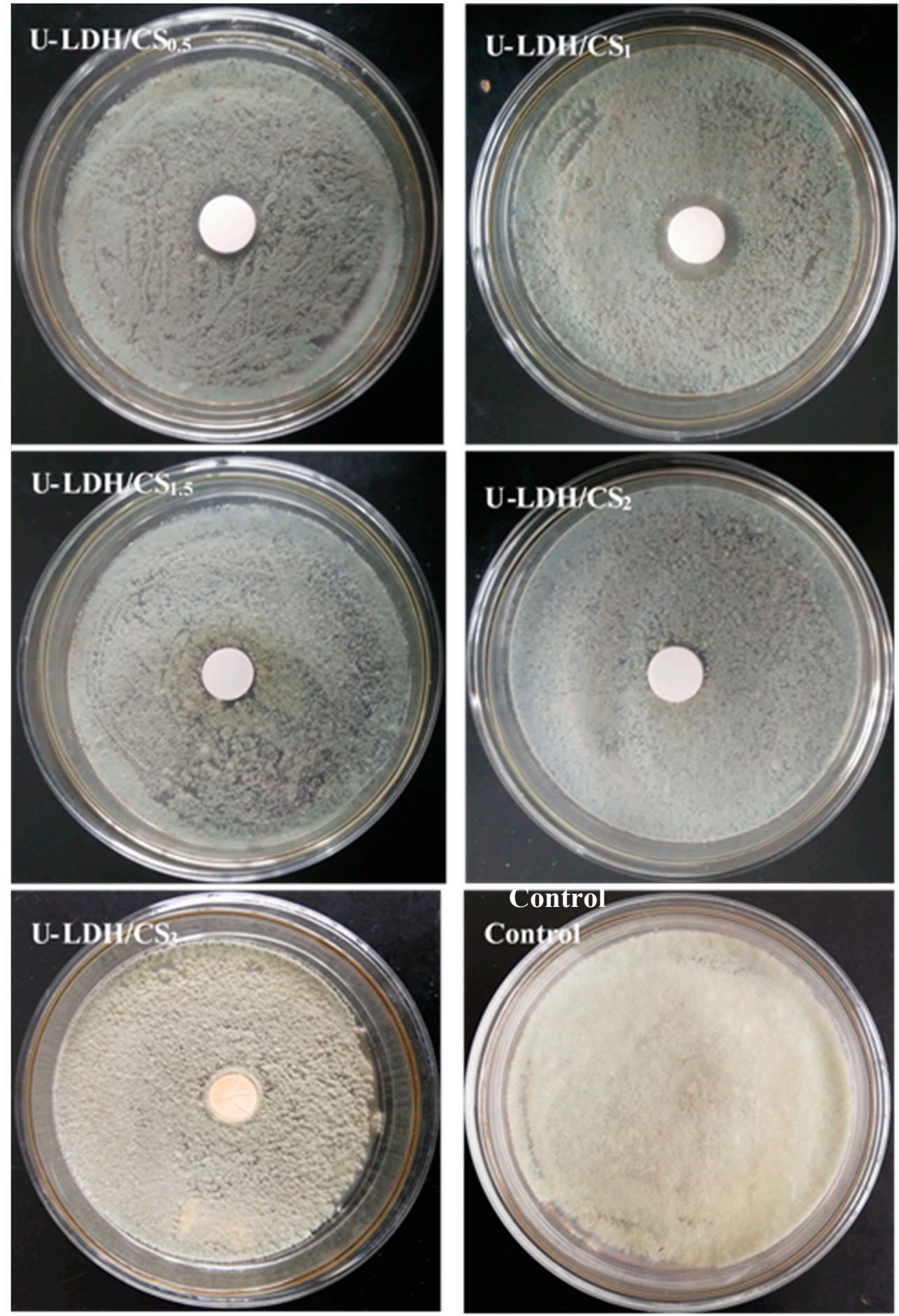

(c)

Figure 9. Inhibition zones of the U-LDH/CS samples and control against (a) E. coli.; (b) S. aureus; (c) P. cyclopium. 
Table 2. Antimicrobial activities of the U-LDH/CS hybrids.

\begin{tabular}{|c|c|c|c|}
\hline Samples g & E. coli & S. aureus & P. cyclopium \\
\hline Control & $0 \mathrm{~mm}$ & $0 \mathrm{~mm}$ & $0 \mathrm{~mm}$ \\
\hline Pure CS & $0 \mathrm{~mm}$ & $0 \mathrm{~mm}$ & $0 \mathrm{~mm}$ \\
\hline U-LDH 5 & $16.5 \pm 0.3 \mathrm{~mm}$ & $20.5 \pm 0.6 \mathrm{~mm}$ & $9.8 \pm 0.7 \mathrm{~mm}$ \\
\hline U-LDH/CS ${ }_{0.5}$ & $18.3 \pm 0.4 \mathrm{~mm}$ & $23.2 \pm 0.2 \mathrm{~mm}$ & $13.3 \pm 0.7 \mathrm{~mm}$ \\
\hline $\mathrm{U}-\mathrm{LDH} / \mathrm{CS}_{1}$ & $24.2 \pm 0.8 \mathrm{~mm}$ & $30.4 \pm 0.5 \mathrm{~mm}$ & $22.3 \pm 0.5 \mathrm{~mm}$ \\
\hline U-LDH/CS ${ }_{1.5}$ & $17.1 \pm 0.3 \mathrm{~mm}$ & $27.0 \pm 0.6 \mathrm{~mm}$ & $0 \mathrm{~mm}$ \\
\hline $\mathrm{U}-\mathrm{LDH} / \mathrm{CS}_{2}$ & $0 \mathrm{~mm}$ & $14 \mathrm{~mm}$ & $0 \mathrm{~mm}$ \\
\hline $\mathrm{U}-\mathrm{LDH} / \mathrm{CS}_{3}$ & $0 \mathrm{~mm}$ & $0 \mathrm{~mm}$ & $0 \mathrm{~mm}$ \\
\hline Tetracycline* & $21 \pm 0.9 \mathrm{~mm}$ & $26 \pm 0.9 \mathrm{~mm}$ & $21 \pm 0.8 \mathrm{~mm}$ \\
\hline
\end{tabular}

Notes: Values are mean of three replicates; ${ }^{*}$ standard antibiotic.

The antimicrobial inactivity of pure chitosan was reported by Kong et al. in this term: "The antimicrobial activity for chitosan is $\mathrm{pH}$ dependent". The ability of chitosan to inhibit microbial growth is observed only in an acidic medium, where the polymer is soluble and carries a net positive charge $[51,52]$. The failure of chitosan to remain bactericidal at $\mathrm{pH}$ values of around six could be explained by the presence of a large majority of positively uncharged amino groups as well as by the poor solubility of chitosan [53,54]. The $\mathrm{pH}$ of the bacterial culture medium ( $\mathrm{pH}$ 5.7 7.5) inhibits the chelating effect that could cause the chitosan on the bacteria to cause their lysis. Therefore, to overcome this limit, derivatization of chitosan is particularly aimed at enhancing the solubility of chitosan in aqueous medium while improving chitosan antimicrobial properties. As an example, Kong et al. [55] proposed the use of chitosan microsphere (CM) in a solid dispersing system, and even in this case, chitosan, which showed inhibitory effects, had a deacetylation degree DD of $62.6 \%$. Above this value, and especially as reported by Kong et al. [55], in the range 83.5 to 97.5 of DD, CM showed no antimicrobial activity. Furthermore, chitosan with a lower degree of acetylation (DA) resulted in increased antimicrobial activity against various strains of fungi, Gram-positive, and Gram-negative bacteria [56]. The chitosan used in this study had a DA of $91 \%$, which is very high. The lack of antimicrobial activity shown by chitosan could be made worse by the large size of pure chitosan particles, which prevents their entry through the pores of the bacterial membrane. Hence, the inability to cause membrane lysis as might be expected. This explains the importance of hydrolyzing chitosan in order to reduce its molecular and voluminous mass and also associate it with other compounds to protect it, thus enabling it to conserve its electrical charge. The significant antibacterial activity of the U-LDH/CS >> U-LDH >>> CS hybrid is due to the combination of the antibacterial activity of chitosan now protected by its association with the U-LDH and the antibacterial activity of the latter. Using protecting groups presents advantages, such as allowing selective modifications at the reactive centers, allowing reactions in the homogeneous medium, and giving a high degree of substitution in the products [57]. Indeed, the introduction of functional groups, such as trimethyl or quaternary alkyl groups, gives the polymer a permanent positive charge, improving its solubility in an aqueous medium and making it possible to measure the bioactivity at $\mathrm{pH} 7$ [23].

In Figure 9a, against Gram-negative E. coli, the antibacterial activity is marked by the translucent outline around the material hybrid. This can be supported by the mechanism proposed by Dutta et al. [58]. The inactivation of E. coli by chitosan occurred via a two-step sequential mechanism; an initial separation of the cell wall from its cell membrane, followed by destruction of the cell membrane. This is confirmed by the mechanisms proposed by Zeng et al. and Papineau et al. [26,59]. Chitosan, through the hybrid, was reactivated and acted mainly on the outer surface of the bacteria. At a lower concentration $(0.2 \mathrm{mg} / \mathrm{mL})$, the polycationic chitosan does probably bind to the negatively charged bacterial surface to cause agglutination, while at higher concentrations the larger number of positive charges may have imparted a net positive charge to the bacterial surfaces to keep them in suspension. In Figure 9b, against Gram-positive S. aureus, the visible translucent areas are the inhibitions zones, which do not results in the behavior of the hybrid U-LDH/CS towards the bacteria strain. The hybrid 
U-LDH/CS on the surface of the cell (S. aureus) can form a polymer membrane, which inhibits nutrients from entering the cell [26]. The hybrid mechanism on fungi (P. cyclopium), shown in Figure 8c, can be explained by the mechanism described by Bai et al. [60]. Chitosan, after being protected by U-LDH, activated a dual function: (a) to direct the interference of fungal growth and (b) to activate several defense processes. The strong antimicrobial activity shown by the U-LDH/CS hybrid results from a synergistic harmony of the proportions of $\mathrm{ZnAl}-\mathrm{LDH}$ and CS compounds, and the adequation of their combination has activated the activity of the antimicrobial compounds $\mathrm{CS}, \mathrm{Zn}^{2+}, \mathrm{ZnO}$, and $\mathrm{Al}_{2} \mathrm{O}_{3}$ contained in the structure of the hybrid. This could lead to the probable antimicrobial activity mechanisms of the hybrid U-LDH/CS described below.

The antimicrobial mechanism of the hybrid could be compared to that of the chitosan derivative as described by Hosseinnejad and Jafari [61]. It is a multiple action posed by all components of the hybrid taken together or individually. The chitosan molecules of the hybrid, positively charged (cationic $\mathrm{NH}^{3+}$ groups), interfere with negatively charged bacterial cell membranes. This interaction with the bacteria membrane leads to the alteration of cell permeability and membrane lysis [62-64]. The hybrid, via chitosan, could activate a chelation of nutrients, causing the inhibition of microbial growth by the essential metals $[63,65]$. The hybrid could also, through the generation of reactive oxygen species (ROS) through its metallic compounds, cause lysis of the bacterium [66]. The production of ROS is presented as a major contributor to the antibacterial activities of various metal oxides [67]. Such reactive species are superoxide anion $\left(\mathrm{O}^{2}\right)$, hydrogen peroxide $\left(\mathrm{H}_{2} \mathrm{O}_{2}\right)$, and hydroxide $(\mathrm{OH}-)$. The toxicity of these species involves the destruction of cellular components such as lipids, DNA, and proteins as a result of their internalization into the bacteria cell membrane [61]. Beside these mechanisms, it also causes the release of zinc ions $\left(\mathrm{Zn}^{2+}\right)$ in medium containing $\mathrm{ZnO}$ nanoparticles and bacteria $[68,69]$. Released $\mathrm{Zn}^{2+}$ has a significant effect, causing active transport inhibition as well as the disruption of the amino acid metabolism and enzyme systems [70,71]. The probable antimicrobial activity mechanisms of hybrid U-LDH/CS is proposed in Figure 10.

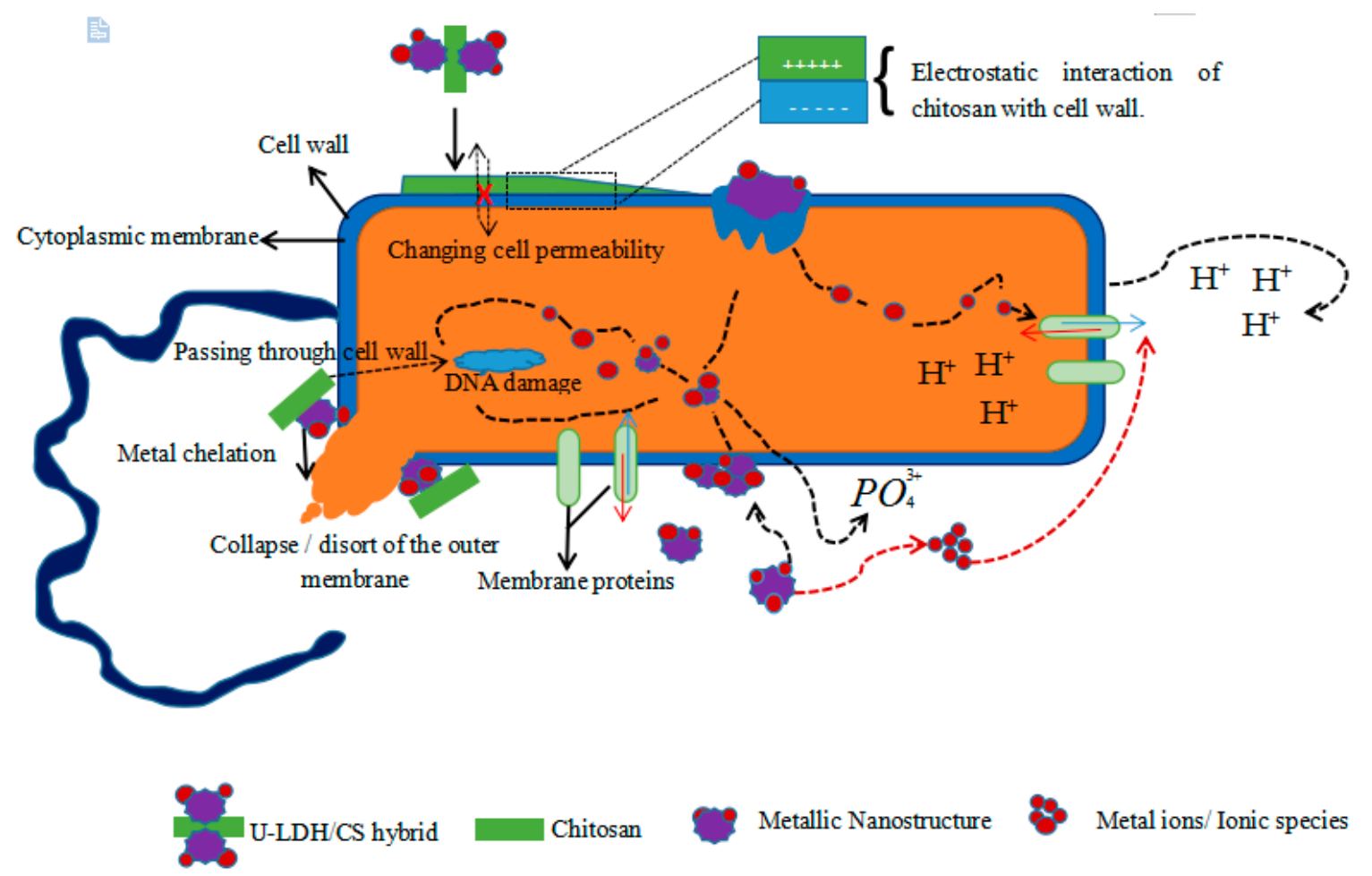

Figure 10. Schematicrepresentation of probable mechanisms involved in U-LDH/CS antimicrobial activity. 
$\mathrm{U}-\mathrm{LDH} / \mathrm{CS}_{2}$ and U-LDH/CS 3 showed either no antimicrobial effect, or a decreased antimicrobial effect. The characterization analysis (UV-Vis, thermogravimetric, and rheological) showed that $\mathrm{U}-\mathrm{LDH} / \mathrm{CS}_{2}$ and U-LDH/CS 3 behaved almost like pure chitosan. It seems that at about $2 \mathrm{~g} \mathrm{~L}^{-1}$ or more of chitosan concentration, $\mathrm{U}-\mathrm{LDH}_{5}$ is either insufficient or unable to firmly attach and protect the chitosan against the $\mathrm{pH}$ of the medium. LDH, which has not been attached to chitosan, has therefore not been able to release in the medium metal oxides and ionic particles. So, the chitosan molecules that are subjected to the $\mathrm{pH}$ of the medium diffuse this $\mathrm{pH}$ effect by their interconnection bond, which considerably reduces the chitosan molecules that have retained their antimicrobial activity. In addition, the large amount of chitosan also disrupts the antibacterial activity of metallic nanostructures released from LDH. This explains why, from $2 \mathrm{~g} \mathrm{~L}^{-1}$ of chitosan concentration, there is a remarkable reduction or loss of the antimicrobial activity of chitosan. This was confirmed by rheological, FTIR, UV-Vis, and thermogravimetric analyses, which indicated that $\mathrm{U}-\mathrm{LDH} / \mathrm{CS}_{3}$ showed fragility to remain compact, with U-LDH/CS 2 and U-LDH/CS 3 absorption bands being more similar to those of chitosan. The amount of chitosan is a significant factor of effectiveness of the antibacterial activity of the hybrid. In the range of 0.5 to $1.5 \mathrm{~g} \mathrm{~L}^{-1}$ of chitosan concentration, its plays a stimulating role in the antimicrobial activity of the hybrid by producing an increase of the antimicrobial activity. This increase of the hybrid antimicrobial activity is shown by the enlargement of the inhibition zones. However, in the range of 1.5 to $3 \mathrm{~g} \mathrm{~L}^{-1}$, chitosan concentration has an inhibitory effect on the antimicrobial activity of the hybrid. This results in a reduction or complete loss of the antimicrobial activity of the hybrid. The concentration of chitosan therefore has a pivotal role in the synthesis and efficacy of the antimicrobial activity of the U-LDH/CS hybrid.

\section{Conclusions}

The development and spread of antibiotic-resistant pathogens involves research to develop new antimicrobial agents. Hybrids derived from chitosan are newly emerging areas of research into the synthesis of antimicrobial agents. Hybridization of chitosan with ZnAl-LDH has the potential to restore the effectiveness of the antibacterial activity of chitosan at a $\mathrm{pH}$ of about six and above, provide novel candidates with a synergistic effect in terms of efficacy and lowered resistance selection propensity, and could confer antibacterial activity against a broad spectrum of resistant microbes. Antibacterial hybrid materials based on the $\mathrm{ZnAl} /$ chitosan matrix have been successfully synthesized. It was shown that the obtained hybrid tested against E. coli, S. aureus, and P. cyclopium demonstrated the highest antimicrobial activity toward S. aureus. It has been found that an increase of CS concentration around and above 1.5 $\mathrm{g} \mathrm{L}^{-1}$ led to a decrease in the antibacterial activity of U-LDH/CS. The effectiveness of the antibacterial activity of U-LDH/CS hybrids suggest that the proposed preparation of such hybrid materials could be extended to the development of other organic-inorganic hybrid antimicrobial materials that may have applications in several areas of biotechnology and medical engineering.

Supplementary Materials: The following are available online at http://www.mdpi.com/2073-4360/11/10/1588/s1. Author Contributions: B.F.C.A.G. and H.-Y.Z. conceived and designed the experiments; B.F.C.A.G., X.-J.C. and K.-M.Z. performed the experiments; B.F.C.A.G., H.-Y.Z., W.S. and Y.D. analyzed the data; H.-Y.Z. contributed reagents/materials/analysis tools; B.F.C.A.G. wrote the paper.

Funding: This work was supported by the National Natural Science Foundation of China (21105085, 31270988) and the Key Project of Hunan Provincial Natural Science Foundation of China (12JJ2008).

Acknowledgments: This work was supported by the National Natural Science Foundation of China (21105085, 31270988) and the Key Project of Hunan Provincial Natural Science Foundation of China (12JJ2008).

Conflicts of Interest: The authors declare no conflict of interest. 


\section{References}

1. Nunes, D.; Pimentel, A.; Santos, L.; Barquinha, P.; Pereira, L.; Fortunato, E.; Martins, R. Textbook of Metal Oxide Nanostructures: Synthesis, Properties and Applications, 1st ed.; Elsevier: North-Holland, The Netherlands, 2018; p. 328.

2. Follmann, H.D.; Messias, I.; Queiroz, M.N.; Araujo, R.A.; Rubira, A.F.; Silva, R. Designing hybrid materials with multifunctional interfaces for wound dressing, electrocatalysis, and chemical separation. J. Colloid Interface Sci. 2019, 533, 106-125. [CrossRef] [PubMed]

3. Ananikov, V.P.; Eremin, D.B.; Yakukhnov, S.A.; Dilman, A.D.; Levin, V.V.; Egorov, M.P.; Karlov, S.S.; Kustov, L.M.; Tarasov, A.L.; Greish, A.A.; et al. Organic and hybrid systems: From science to practice. Mendeleev Commun. 2017, 27, 425-438. [CrossRef]

4. Toshima, N. Recent progress of organic and hybrid thermoelectric materials. Synth. Met. 2017, $225,3-21$. [CrossRef]

5. Sirinakorn, T.; Imwiset, K.; Bureekaew, S.; Ogawa, M. Inorganic modification of layered silicates toward functional inorganic-inorganic hybrids. Appl. Clay Sci. 2018, 153, 187-197. [CrossRef]

6. Jo, Y.K.; Lee, J.M.; Son, S.; Hwang, S.J. 2D inorganic nanosheet-based hybrid photocatalysts: Design, applications, and perspectives. J. Photochem. Photobiol. C Photochem. Rev. 2018, 40, 150-190. [CrossRef]

7. Zhu, J.; Wen, M.; Wen, W.; Du, D.; Zhang, X.; Wang, S.; Lin, Y. Recent progress in biosensors based on organic-inorganic hybrid nanoflowers. Biosens. Bioelectron. 2018, 120, 175-187. [CrossRef] [PubMed]

8. Ma, Y.; Chen, L.; Ye, Y.; Wan, H.; Zhou, H.; Chen, J. Preparation and tribological behaviors of a novel organic-inorganic hybrid resin bonded solid lubricating coating cured by ultraviolet radiation. Prog. Org. Coat. 2019, 127, 348-358. [CrossRef]

9. Sharaha, U.; Rodriguez-Diaz, E.; Riesenberg, K.; Bigio, I.J.; Huleihel, M.; Salman, A. Using Infrared Spectroscopy and Multivariate Analysis to Detect Antibiotics' Resistant Escherichia coli Bacteria. Anal. Chem. 2017, 89, 8782-8790. [CrossRef]

10. Gagnon, K.J.; Perry, H.P.; Clearfield, A. Chem Inform Abstract: Conventional and Unconventional Metal-Organic Frameworks Based on Phosphonate Ligands: MOFs and UMOFs. Chem. Rev. 2012, 43, 1034-1054. [CrossRef]

11. Zhang, T.; Zhou, Y.; Wang, Y.; Zhang, L.; Wang, H.; Wu, X. Fabrication of hierarchical nanostructured BSA/ZnO hybrid nanoflowers by a self-assembly process. Mater. Lett. 2014, 128, 227-230. [CrossRef]

12. Wang, X.; Lou, T.; Zhao, W.; Song, G. Preparation of pure chitosan film using ternary solvents and its super absorbency. Carbohydr. Polym. 2016, 153, 253-257. [CrossRef] [PubMed]

13. Ge, H.C.; Hua, T.T. Synthesis and characterization of poly (maleic acid)-grafted crosslinked chitosan nanomaterial with high uptake and selectivity for $\mathrm{Hg}$ (II) sorption. Carbohyd. Polym. 2016, 153, $246-252$. [CrossRef] [PubMed]

14. Zubair, M.; Daud, M.; McKay, G.; Shehzad, F.; Al-Harthi, M.A. Recent progress in layered double hydroxides (LDH)-containing hybrids as adsorbents for water remediation. Appl. Clay Sci. 2017, 143, 279-292. [CrossRef]

15. Khan, S.; Kamal, T.; Asiri, A.; Akhtar, K.; Khan, S. Recent Development of Chitosan Nanocomposites for Environmental Applications. Recent Pat. Nanotechnol. 2016, 10, 181-188. [CrossRef] [PubMed]

16. Choi, C.; Nam, J.-P.; Nah, J.-W. Application of chitosan and chitosan derivatives as biomaterials. J. Ind. Eng. Chem. 2016, 33, 1-10. [CrossRef]

17. Thomas, V.; Yallapu, M.M.; Sreedhar, B.; Bajpai, S.K. Fabrication, Characterization of Chitosan/Nanosilver Film and Its Potential Antibacterial Application. J. Biomater. Sci. Polym. Ed. 2009, 20, 2129-2144. [CrossRef]

18. Ruiz-Hitzky, E.; Aranda, P.; Darder, M.; Rytwo, G. Hybrid materials based on clays for environmental and biomedical applications. J. Mater. Chem. 2010, 20, 9306. [CrossRef]

19. Cunha, V.R.R.; Guilherme, V.A.; De Paula, E.; De Araujo, D.R.; Silva, R.O.; Medeiros, J.V.R.; Leite, J.R.S.A.; Peterson, P.A.D.; Foldvari, M.; Petrilli, H.M.; et al. Delivery system for mefenamic acid based on the nanocarrier layered double hydroxide: Physicochemical characterization and evaluation of anti-inflammatory and antinociceptive potential. Mater. Sci. Eng. C 2016, 58, 629-638. [CrossRef]

20. Ferraris, S.; Spriano, S. Review Antibacterial titanium surfaces for medical implants. Adv. Mater. Sci. Eng.C 2016, 61, 965-978. [CrossRef]

21. Mishra, G.; Dash, B.; Pandey, S.; Mohanty, P.P. Antibacterial actions of silver nanoparticles incorporated Zn-Al layered double hydroxide and its spinel. J. Environ. Chem. Eng. 2013, 1, 1124-1130. [CrossRef] 
22. Li, B.; Zhang, Y.; Yang, Y.; Qiu, W.; Wang, X.; Liu, B.; Wang, Y.; Sun, G. Synthesis, characterization, and antibacterial activity of chitosan/ $\mathrm{TiO}_{2}$ nanocomposite against Xanthomonas oryzae pv. oryzae. Carbohydr. Polym. 2016, 152, 825-831. [CrossRef] [PubMed]

23. Sahariah, P.; Másson, M. Antimicrobial Chitosan and Chitosan Derivatives: A Review of the Structure-Activity Relationship. Biomacromolecules 2017, 18, 3846-3868. [CrossRef] [PubMed]

24. Liu, H.; Du, Y.; Wang, X.; Sun, L. Chitosan kills bacteria through cell membrane damage. Int. J. Food Microbiol. 2004, 95, 147-155. [CrossRef] [PubMed]

25. Helander, I.; Nurmiaho-Lassila, E.-L.; Ahvenainen, R.; Rhoades, J.; Roller, S. Chitosan disrupts the barrier properties of the outer membrane of Gram-negative bacteria. Int. J. Food Microbiol. 2001, 71, 235-244. [CrossRef]

26. Zheng, L.Y.; Zhu, J.F. Study of antimicrobial activity of chitosan with different molecular weight. Carbohyd. Polym. 2003, 54, 527-530. [CrossRef]

27. Zeng, H.-Y.; Deng, X.; Wang, Y.-J.; Liao, K.-B. Preparation of Mg-Al hydrotalcite by urea method and its catalytic activity for transesterification. AIChE J. 2009, 55, 1229-1235. [CrossRef]

28. Li, S.-P.; Hou, W.-G.; Han, S.-H.; Li, L.-F.; Zhao, W.-A. Studies on intrinsic ionization constants of Fe-Al-Mg hydrotalcite-like compounds. J. Colloid Interface Sci. 2003, 257, 244-249. [CrossRef]

29. Barka, E.A.; Gognies, S.; Nowak, J.; Audran, J.-C.; Belarbi, A. Inhibitory effect of endophyte bacteria on Botrytis cinerea and its influence to promote the grapevine growth. Biol. Control 2002, 24, 135-142. [CrossRef]

30. Yi, J.-Z.; Zhang, L.-M. Studies of sodium humate/polyacrylamide/clay hybrid hydrogels. I. Swelling and rheological properties of hydrogels. Eur. Polym. J. 2007, 43, 3215-3221. [CrossRef]

31. Zheng, Z.; Levin, R.E.; Pinkham, J.L.; Shetty, K. Decolorization of polymeric dyes by a novel Penicillium isolate. Process Biochem. 1999, 34, 31-37. [CrossRef]

32. Hou, W.-G.; Su, Y.-L.; Sun, D.-J.; Zhang, C.-G. Studies on Zero Point of Charge and Permanent Charge Density of Mg-Fe Hydrotalcite-like Compounds. Langmuir 2001, 17, 1885-1888. [CrossRef]

33. Jahangirian, H.; Haron, M.J.; Shah, M.H.; Abdollahi, Y.A.; Rezayi, M.A.; Vafaei, N.A. Well diffusion method for evaluation of antibacterial activity of copper phenyl fatty hydroxamate synthesized from canola and palm kernel oils. Dig. J. Nanomater. Biostruct. 2013, 8, 1263-1270.

34. Luo, L.; Li, Q.; Xu, Y.; Ding, Y.; Wang, X.; Deng, D.; Xu, Y. Amperometric glucose biosensor based on NiFe2O4 nanoparticles and chitosan. Sens. Actuators B Chem. 2010, 145, 293-298. [CrossRef]

35. Viswanathan, N.; Meenakshi, S. Enriched fluoride sorption using alumina/chitosan composite. J. Hazard. Mater. 2010, 178, 226-232. [CrossRef] [PubMed]

36. Si, Y.; Samulski, E.T. Synthesis of water soluble grapheme. Nano Lett. 2008, 8, 1679-1682. [CrossRef] [PubMed]

37. Pawlak, A.; Mucha, M. Thermogravimetric and FTIR studies of chitosan blends. Thermochim. Acta 2003, 396, 153-166. [CrossRef]

38. Darder, M.; Colilla, M.; Ruiz-Hitzky, E. Chitosan-clay nanocomposites: Application as electrochemical sensors. Appl. Clay Sci. 2005, 28, 199-208. [CrossRef]

39. Darder, M.; Colilla, M.; Ruiz-Hitzky, E. Biopolymer-Clay Nanocomposites Based on Chitosan Intercalated in Montmorillonite. Chem. Mater. 2003, 15, 3774-3780. [CrossRef]

40. Krishnamoorti, R.; Giannelis, E.P. Rheology of End-Tethered Polymer Layered Silicate Nanocomposites. Macromology 1997, 30, 4097-4102. [CrossRef]

41. Costa, F.R.; Wagenknecht, U.; Jehnichen, D.; Goad, M.A.; Heinrich, G. Nanocomposites based on polyethylene and Mg-Al layered double hydroxide. Part II. Rheological characterization. Polymer 2006, 47, 1649-1660. [CrossRef]

42. Cárdenas, G.; Miranda, S.P. FTIR and TGA studies of chitosan composite films. J. Chil. Chem. Soc. 2004, 49, 291-295. [CrossRef]

43. Kumar, S.; Koh, J. Physiochemical, Optical and Biological Activity of Chitosan-Chromone Derivative for Biomedical Applications. Int. J. Mol. Sci. 2012, 13, 6102-6116. [CrossRef] [PubMed]

44. Taboada, E. Retención de Metales Pesados Utilizando Quitosano y Derivados. Ph.D. Thesis, Universidad de Concepción, Concepción, Chile, January 2003.

45. Vágvölgyi, V.; Palmer, S.J.; Kristóf, J.; Frost, R.L.; Horváth, E. Mechanism for hydrotalcite decomposition: A controlled rate thermal analysis study. J. Colloid Interface Sci. 2008, 318, 302-308. [CrossRef] [PubMed] 
46. Tichit, D.; Rolland, A.; Prinetto, F.; Fetter, G.; Martinez-Ortiz, M.D.J.; Valenzuela, M.A.; Bosch, P. Comparison of the structural and acid???base properties of Ga- and Al-containing layered double hydroxides obtained by microwave irradiation and conventional ageing of synthesis gels. J. Mater. Chem. 2002, 12, 3832-3838. [CrossRef]

47. Ahmed, A.A.A.; Talib, Z.A.; Bin Hussein, M.Z. Thermal, optical and dielectric properties of Zn-Al layered double hydroxide. Appl. Clay Sci. 2012, 56, 68-76. [CrossRef]

48. Auwalu, A.; Linlin, T.; Ahmad, S.; Hongying, Y.; Zhenan, J.; Song, Y. Preparation and application of metal ion-doped CoMgAl-hydrotalcite visible-light-driven photocatalyst. Int. J. Ind. Chem. 2019, 10, 121-131. [CrossRef]

49. Elhalil, A.; Elmoubarki, R.; Machrouhi, A.; Sadiq, M.; Abdennouri, M.; Qourzal, S.; Barka, N. Photocatalytic degradation of caffeine by $\mathrm{ZnO}-\mathrm{ZnAl} 2 \mathrm{O} 4$ nanoparticles derived from $\mathrm{LDH}$ structure. J. Environ. Chem. Eng. 2017, 5, 3719-3726. [CrossRef]

50. Kong, M.; Chen, X.G.; Xing, K.; Park, H.J. Antimicrobial properties of chitosan and mode of action: A state of the art review. Int. J. Food Microbiol. 2010, 144, 51-63. [CrossRef]

51. Simunek, J.; Brandysova, V.; Koppova, I.; Simunek, J., Jr. The antimicrobial action of chitosan, low molar mass chitosan, and chitooligosaccharides on human colonic bacteria. Folia Microbiol. 2012, 57, 341-345. [CrossRef]

52. Jung, E.J.; Youn, D.K.; Lee, S.H.; No, H.K.; Ha, J.G.; Prinyawiwatkul, W. Antibacterial activity of chitosans with different degrees of deacetylation and viscosities. Int. J. Food Sci. Technol. 2010, 45, 676-682. [CrossRef]

53. Aiedeh, K.; Taha, M.O. Synthesis of iron-crosslinked chitosan succinate and iron-crosslinked hydroxamated chitosan succinate and their in vitro evaluation as potential matrix materials for oral theophylline sustained-release beads. Eur. J. Pharm. Sci. 2001, 13, 159-168. [CrossRef]

54. Sudarshan, N.R.; Hoover, D.G.; Knorr, D. Antibacterial action of chitosan. Food Biotechnol. 1992, 6, $257-272$. [CrossRef]

55. Kong, M.; Chen, X.G.; Liu, C.S.; Yu, L.J.; Ji, Q.X.; Xue, Y.P.; Cha, D.S.; Park, H.J. Preparation and antibacterial activity of chitosan microspheres in a solid dispersing system. Front. Mater. Sci. 2008, 2, 214-220. [CrossRef]

56. Andres, Y.; Giraud, L.; Gerente, C.; Le Cloirec, P. Antibacterial Effects of Chitosan Powder: Mechanisms of Action. Environ. Technol. 2007, 28, 1357-1363. [CrossRef] [PubMed]

57. Sahariah, P.; Óskarsson, B.M.; Hjálmarsdóttir, M.A.; Másson, M. Synthesis of guanidinylated chitosan with the aid of multiple protecting groups and investigation of antibacterial activity. Carbohydr. Polym. 2015, 127, 407-417. [CrossRef]

58. Dutta, P.; Tripathi, S.; Mehrotra, G.; Dutta, J. Perspectives for chitosan based antimicrobial films in food applications. Food Chem. 2009, 114, 1173-1182. [CrossRef]

59. Papineau, A.M.; Hoover, D.G.; Knorr, D.; Farkas, D.F. Antimicrobial effect of water-soluble chitosans with high hydrostatic pressure. Food Biotechnol. 1991, 5, 45-57. [CrossRef]

60. Bai, R.-K.; Huang, M.-Y.; Jiang, Y.-Y. Selective permeabilities of chitosan-acetic acid complex membrane and chitosan-polymer complex membranes for oxygen and carbon dioxide. Polym. Bull. 1988, 20, 83-88. [CrossRef]

61. Hosseinnejad, M.; Jafaria, S.M. Evaluation of different factors affecting antimicrobial properties of chitosan. Int. J. Biol. Macromol. 2016, 85, 467-475. [CrossRef] [PubMed]

62. Severino, R.; Vu, K.D.; Donsi', F.; Salmieri, S.; Ferrari, G.; Lacroix, M. Antimicrobial effects of different combined non-thermal treatments against Listeria monocytogenes in broccoli florets. J. Food Eng. 2014, 124, 1-10. [CrossRef]

63. Chien, R.-C.; Yen, M.-T.; Mau, J.-L. Antimicrobial and antitumor activities of chitosan from shiitake stipes, compared to commercial chitosan from crab shells. Carbohydr. Polym. 2016, 138, 259-264. [CrossRef] [PubMed]

64. Li, Z.; Yang, F.; Yang, R. Synthesis and characterization of chitosan derivatives with dual-antibacterial functional groups. Int. J. Biol. Macromol. 2015, 75, 378-387. [CrossRef] [PubMed]

65. Yuan, G.; Lv, H.; Tang, W.; Zhang, X.; Sun, H. Effect of chitosan coating combined with pomegranate peel extract on the quality of Pacific white shrimp during iced storage. Food Control 2016, 59, 818-823. [CrossRef]

66. Zhang, H.; Lv, X.-J.; Li, Y.; Wang, Y.; Li, J. P25-Graphene Composite as a High Performance Photocatalyst. ACS Nano 2009, 4, 380-386. [CrossRef] [PubMed] 
67. Prasad, R.; Basavaraju, D.; Rao, K.; Naveen, C.; Endrino, J.; Phani, A. Nanostructured $\mathrm{TiO}_{2}$ and TiO $\mathrm{T}_{2}-\mathrm{Ag}$ antimicrobial thin fifilms. In Proceedings of the 2011 International Conference on Nanoscience, Technology and Societal Implications (NSTSI), Bhubaneswar, India, 8-10 December 2011.

68. Premanathan, M.; Karthikeyan, K.; Jeyasubramanian, K.; Manivannan, G. Selective toxicity of ZnO nanoparticles toward Gram-positive bacteria and cancer cells by apoptosis through lipid peroxidation. Nanomed. Nanotechnol. Biol. Med. 2011, 7, 184-192.

69. Li, M.; Zhu, L.; Lin, D. Toxicity of ZnO nanoparticles to Escherichia coli: Mechanism and the inflfluence of medium components. Environ. Sci. Technol. 2011, 45, 1977-1983. [CrossRef] [PubMed]

70. Wong, S.W.; Leung, P.T.; Djurišić, A.B.; Leung, K.M. Toxicities of nano zinc oxide to five marine organisms: Influences of aggregate size and ion solubility. Anal. Bioanal. Chem. 2010, 396, 609-618. [CrossRef] [PubMed]

71. Wu, B.; Wang, Y.; Lee, Y.-H.; Horst, A.; Wang, Z.; Chen, D.-R.; Sureshkumar, R.; Tang, Y.J. Comparative Eco-Toxicities of Nano-ZnO Particles under Aquatic and Aerosol Exposure Modes. Environ. Sci. Technol. 2010, 44, 1484-1489. [CrossRef] [PubMed]

(C) 2019 by the authors. Licensee MDPI, Basel, Switzerland. This article is an open access article distributed under the terms and conditions of the Creative Commons Attribution (CC BY) license (http://creativecommons.org/licenses/by/4.0/). 